\title{
Do Industry Growth Prospects Drive IPO Stock Performance?
}

\author{
Ming Dong ${ }^{\dagger}$ \\ and \\ Jean-Sébastien Michel ${ }^{*}$
}

Current Version: March 2011

\footnotetext{
${ }^{\dagger}$ Associate Professor of Finance, Schulich School of Business, York University, Toronto, Ontario, M3J 1P3, Canada. E-mail: mdong @ ssb.yorku.ca. Phone: (416) 736-2100 ext 77945. Fax: (416) 736-5687

* Assistant Professor of Finance, HEC Montréal, Montréal, Québec, H3T 2A7, Canada.

E-mail: jean-sebastien.michel@ hec.ca. Phone: (514) 340-7153. Fax: (514) 340-5632

We thank Ling Cen, Honghui Chen, Douglas Cumming, Espen Eckbo, Alex Edmans, Steve Foerster, Huasheng Gao, Al Goss, John Griffin, David Hirshleifer, Mark Kamstra, Ambrus Kecskes, Tim Loughran, Debarshi Nandy, Gordon Roberts, Sam Tibbs, Xiaoyun Yu, Donghang Zhang, and seminar participants at York University for very helpful comments.
} 


\title{
Do Industry Growth Prospects Drive IPO Stock Performance?
}

\begin{abstract}
We examine the relation between an ex ante measure of IPO growth prospects - the industrylevel analyst earnings growth forecast - and short- and long-run IPO performances, using a sample of 7,608 IPOs from 1982 to 2007 . We find that in the period before the Internet bubble (1999-2000), IPOs in industries with high growth prospects earn high short-run and long-run returns up to three years after the IPO. Industry growth has the largest economic impact on longrun performance among all factors we consider including underwriter quality and offer proceeds. However, during the Internet bubble period, the effect of industry growth on long-run performance dramatically reverses so that IPOs in high-growth industries underperform in the long run. There is some weak evidence that this reversal has lingered in effect since the bust of the Internet bubble. Our evidence suggests that barring bubble period overreaction to growth prospects, IPO investors tend to underreact to industry growth prospects, leading to superior longrun performance for firms in high-growth industries.
\end{abstract}

JEL classification: G11, G12, G14, G32

Keywords: industry growth; analyst earnings forecast; IPOs; under- and overreactions; short- and long-run performances 


\section{Introduction}

Initial public offering (IPO) investors constantly face a dilemma: more information is needed for IPO companies than for established public companies because of the high uncertainty about IPO valuation and growth prospects, yet the information about IPO firms is sparser. Recent interest in investing in the social network firms such as Facebook, Twitter and Groupon before they go public has highlighted the desire for more information about prospective IPO firms. ${ }^{1}$ In this paper, we investigate whether an intuitive but largely overlooked measure of IPO growth prospects - the growth prospects of the IPO firm's industry - can help investors select IPOs. We hypothesize that to the extent that investors with limited attention categorize an IPO by its industry in assessing its growth prospects, industry earnings growth rate should be a reasonable approximation for investors' outlook on firm growth. We use the analyst long-term earnings growth forecast for the IPO firm's industry as a proxy for the IPO's growth potential, and examine whether industry growth prospects affect IPO short-run and long-run stock performances.

A priori, it is unclear how industry growth prospects should affect IPO stock performance, especially the long-run performance. One might expect high growth prospects to be associated with high information asymmetry or high risk, and therefore these IPOs should have high short-run returns due to the traditional arguments such as winner's curse or information revelation of informed investors. However, theories based on information asymmetry or risk do not address the long-run performance of IPOs. In fact, when the aftermarket is fully rational, there should be no predictable relation between industry growth measures and long-run risk-adjusted stock performance.

Alternatively, one could hypothesize that IPO participants do not process information correctly, and may either underreact or overreact to earnings growth prospects. If they underreact to the growth prospects of IPOs, they may set the offer price and/or the first-day closing price too

\footnotetext{
${ }^{1}$ See, e.g., http://www.marketwatch.com/story/be-a-smart-buyer-of-facebook-other-hot-shares-2011-02-04.
} 
low, for IPOs with high growth prospects. Under this underreaction scenario, IPOs with high growth prospects should have better long-run returns because of the initial underreaction to the positive growth potential. Conversely, if investors overreact to information about growth prospects, they may be overoptimistic about IPOs with high growth prospects at the time of the offer, leading to high short-run but poor long-run stock performance. In sum, theory does not have a clear prediction about the relation between industry growth and IPO returns. This needs be resolved empirically.

Using a sample of 7,608 IPOs from 1982 to 2007, we test whether industry growth prospects drive IPO stock performance. We use analyst long-term earnings forecast, valuedweighted across firms in each industry, to measure industry growth prospects. We examine the bubble period (01/1999-12/2000) observations separately, because investors may react to growth prospects differently or have a change in their objective functions during the bubble period, and standard Fama-French risk adjustment methodology may not be appropriate for Internet bubble IPOs (Ritter and Welch (2002)). We therefore break the full sample into three periods: prebubble, bubble, and post-bubble.

For the pre-bubble period observations, when we sort IPOs into three portfolios by industry growth in event time, we find that high growth IPOs have $65 \%$ higher mean styleadjusted (matched on size and book-to-market ratio) returns over a 2-year period after the offer than low growth IPOs. Furthermore, the effect is even stronger among larger IPOs: the 2-year abnormal return spread between low and high industry growth portfolios increases to a striking $191 \%$ when returns are value-weighted. However, the effect of industry growth prospects on long-run returns reverses during the bubble period: IPOs in high growth industries earn $52 \%$ (66\%) lower equal-weighted (value-weighted) style-adjusted 2-year returns than IPOs in low growth industries. In both periods, industry growth is positively associated with short-run price performance, measured by either the offer price adjustment or the first-day returns. These results suggest that outside of the bubble period, investors tend to underreact to growth prospects of the 
IPO's industry, which causes the continual superior return of IPOs in high growth industries. Conversely, investors appear to overreact to industry prospects in the bubble years.

We confirm our findings in multivariate tests that examine the effect of industry growth on both short-run and long-run returns. When we run event-time cross-sectional regressions of long-run risk-adjusted returns on industry growth and a host of controls, we find that industry growth has a significantly positive relation with long-run returns, confirming the portfolio test results. Strikingly, the multivariate tests suggest that among all the factors we examine (including underwriter reputation, the number of managing underwriters, and expected proceeds), industry growth has the strongest effect on long-run returns. For example, in the pre-bubble period $(77.6 \%$ of the full sample), a one standard deviation increase in industry growth rate forecast leads to a $51 \%$ increase in 3-year style-adjusted return, larger than the next strongest effect of underwriter reputation, which has a corresponding impact of $40 \%$ on 3-year abnormal return. Again consistent with the portfolio test, the regression test also indicates that industry growth has a negative effect on the long-run performance of IPOs during the bubble years.

In the post-bubble period, there is some evidence that industry growth continues to have a negative effect on long-run returns up to 2 years after the offer, but the economic and statistical significance levels are much weaker compared to previous periods. (A summary of economic impact of the variables on short-run and long-run performances is provided in the Appendix Table.) In addition, post-bubble IPO withdrawals are more likely to be observed in high growth industries, in contrast with the opposite association between withdrawal and industry growth prior to and during the bubble.

In sum, our evidence suggests that barring bubble period overreaction to growth prospects, IPO investors tend to underreact to industry growth prospects, leading to the superior long-run performance for firms in high-growth industries. In the post-bubble period, investors appear to have a distaste for IPOs in high growth industries, presumably triggered by the burst of the Internet bubble. 
Finally, the divergence of opinion theory posits that in an IPO market with restricted short selling prior to the offer, the IPO price is determined by the most optimistic investors. This biases the price upward in the short-run and leads to a reversal in the long-run as short-sales restrictions are relaxed. According to this theory, the divergence of opinion about industry growth prospects, not industry growth rate per se, leads to high short-run returns and low long-run performance of IPOs. In our event-time regressions, we control for an ex ante measure of divergence of investor opinion about industry growth - the standard deviation of analyst longterm growth forecast scaled by the mean forecast - among other controls. In the pre-bubble period, this variable is insignificant in the long-run return regressions, suggesting that it is the collective misreaction of the market to industry growth prospects rather than the divergence of opinion among investors that drives the differences in long-run IPO performance in normal times. However, there is some evidence that during and after the bubble, belief dispersion has a negative effect on long-run IPO returns, which is consistent with the interpretation that the Miller (1977) effect plays a limited role in IPO performance.

An important advantage of using an industry-level growth proxy is that it circumvents the need of identifying comparable firms, an often noisy process. Moreover, instead of relying on specific valuation multiples, all we require is that the industry-level growth is correlated with the IPO firm's growth. This reduces misspecification problems both in identifying comparable firms and in specifying valuation metrics, while keeping the sample IPOs to a maximum. Valuation metrics are endogenous to investor reaction since these metrics use a market price which may already reflect investors' reactions to growth prospects. Finally, our measure of growth prospects is ex ante to the IPO, which is critical for distinguishing hypotheses. (Section 2 offers a more detailed discussion on measures of growth prospects and divergence of opinion in relation to the literature.) These considerations help explain why we can uncover an economically significant driver of IPO stock performance with a relatively easy-to-construct measure of IPO growth prospects. 
The rest of the paper is organized as follows. Section 2 develops the hypotheses and describes measures of industry growth prospects and divergence of opinion. Section 3 describes the data, methodology, and summary statistics of our IPO sample. Section 4 describes crosssectional tests on the short-run and long-run stock performances. Section 5 presents calendar-time long-run performance tests. Section 6 describes the effects of industry growth on IPO withdrawal. Section 7 discusses the interpretations of the empirical findings. Section 8 concludes.

\section{Hypotheses and Measures of Growth Prospects}

We examine the relation between industry growth measures and IPO short- and long-run stock performances in light of three hypotheses. In this section, we first describe these hypotheses, followed by a discussion of our measure of industry growth prospects and belief dispersion, and a summary of the empirical implications of the hypotheses on short- and long-run returns.

\subsection{Information Asymmetry / Risk}

Traditional theories assume market efficiency and treat the first-day closing price as the correct value of the IPO, which implies that IPOs are on average deeply underpriced at the offer. For example, Rock (1986) proposes a winner's curse interpretation whereby underpricing is necessary to induce uninformed investors to participate in the offering. Benveniste and Spindt (1989) link underpricing to truth-telling of investors in the book-building process. Chemmanur and Fulghieri (1994) and Loughran and Ritter (2004) relate underpricing to underwriter reputation or a changing issuer objective function. Accordingly, firms with high information asymmetry, or equivalently, high-uncertainty or risk, as measured by high growth prospects, require larger underpricing to either attract uninformed investors to participate to the offer or to encourage more information revelation. 
However, these theories do not address the long-run performance of IPOs. In fact, since information is quickly reflected in the price after the offer, there should be no predictable relation between publicly available information, including industry growth measures, and long-run riskadjusted stock performance.

\subsection{Under- or Overreaction to Growth Prospects}

Investors suffering cognizance biases do not process information correctly, and may exhibit systematic under- or overreactions to earnings growth prospects. If market participants tend to underreact to information about the growth prospects of IPOs, as predicted by models such as Barberis, Shleifer, and Vishny (1998) and Hong and Stein (1999), they may set the offer price too low, and / or set the first-day closing price too low, for IPOs with high growth prospects. Under the underreaction scenario, IPOs with high growth prospects should have better long-run returns because of the initial underreaction to the positive growth potential. Moreover, the relation between expected growth potential and short-run price performance is expected to be positive, if the initial price only partially reflects information about industry growth.

Conversely, it is possible that investors tend to overreact to information about growth prospects. More specifically, they may be over-optimistic (pessimistic) about IPOs with high (low) growth prospects (e.g., Daniel, Hirshleifer, and Subrahmanyam (1998)), leading to high (low) first-day returns and poor (high) abnormal long-run performance as the initial overreaction is corrected over time.

\subsection{Divergence of Opinion}

Although it is not the focus of this study, we also control for any potential effect of the divergence of opinion theory proposed by Miller (1977). This theory posits that in a market with restricted short selling, the price of a risky security is determined by the most optimistic investors. This is because pessimistic investors are unable to short-sell shares, thus muting their assessment. 
This biases the share price upward in the short-run and leads to a reversal in the long-run as shortsales restrictions are relaxed.

As discussed in Miller (1977), IPOs are a good testing arena for the divergence of opinion hypothesis for three reasons. First, short-selling is not possible prior to the offer, which allows the impact of divergence of opinion to play out to the fullest extent before the offer. Second, IPO firms face greater uncertainty and divergence of opinions than "seasoned" firms, again because there is no trading record at the time of the offering. Finally, as information builds up in the after-market, uncertainty and divergence of opinion are reduced and the price should decline to its fundamental value. So, the Miller hypothesis predicts initial overpricing and subsequent underperformance.

\subsection{Measures of Growth Prospects and Divergence of Opinion}

Prior research has used accounting based valuation metrics of comparable firms to value IPOs (e.g., Kim and Ritter (1999) and Purnanandam and Swaminathan (2004)). In this paper, we take a different approach. Instead of using specific valuation ratios such as price-to-earnings or price-to-sales, we simply use the expected growth rate of the IPO's industry to gauge the growth prospects of the IPO firm.

Recent literature in financial economics documents an important role for limited attention, a phenomenon documented in psychology (Kahneman (1973)), on investor behavior and financial markets. For example, Hirshleifer and Teoh (2003) show that firms may strategically choose alternatives means of financial reporting when investors have limited attention and processing power. Hirshleifer, Hou, Teoh, Zhang (2004) document that investors with limited attention often focus on accounting profitability and neglect information about cash profitability. Corwin and Coughenour (2007) show that NYSE specialists allocate effort toward their most active stocks during periods of increased activity. Hirshleifer, Lim, and Teoh (2008) document that limited attention causes investors to underreact to earnings news. Cen et al. (2007) 
document a strong lead-lag relationship between stock returns of minor segment firms and pure players in industry leaders' major segment industries, and that this relationship is driven by the representativeness bias of attention-constrained investors.

Given that investors have limited attention resource while information is vast, one of investors' most natural solutions is "categorization", a tendency of investors to categorize assets into certain "visible" or "recognizable" categories. Investors often categorize securities into "small stocks", "tech stocks", "Internet stocks", "dividend-paying stocks", and so forth. There are investors who do not pay much attention beyond categorization when analyzing securities (Cooper, Dimitrov, and Rau (2001), Barberis and Shleifer (2003), Barberis, Shleifer, and Wurgler (2004), Baker and Wurgler (2004), and Barber and Odean (2008)). In the model of Peng and Xiong (2006), it may be optimal for attention-constrained investors to neglect firm-specific information.

Perhaps the most salient feature about a firm is its industry; in the case of an IPO, industry is also a firm's most recognizable feature prior to the offering. The role of industry on stock returns and information flow are well-documented (e.g., Barberis, Shleifer, and Wurgler (2004), Hou (2006), and Cen et al. (2007)). This analysis implies that attention-constrained investors will categorize IPOs by their industries. Edelen and Kadlec (2005) and Wang, Winton, and $\mathrm{Yu}$ (2009) show that the IPO's industry provides reasonable comparables for IPO characteristics. For these reasons, we use analyst earnings growth forecast for the IPO's industry as our proxy for the growth prospects of the IPO. IPOs firms are typically young and in their early stages of growth, so long-term growth rate is a better reflection of their growth prospects. Therefore, we measure industry growth by the value-weighted average of the mean analyst longterm earnings growth forecasts in the IPO firm's industry in the month prior to the offer. ${ }^{2} \mathrm{We}$ denote this variable by IGROW.

\footnotetext{
${ }^{2}$ We use value-weighted average of growth rates because growth forecasts of large firms should better reflect the growth prospects of an industry, and hence should have more weights in constructing industry
} 
The divergence of opinion hypothesis of Miller (1977) requires an estimate for belief dispersion. Several studies use analyst earnings forecast to measure IPO growth prospects (e.g., Wang, Winton, and Yu (2010)) and its dispersion as a proxy for divergence of opinion (e.g., Diether, Malloy, and Scherbina (2002) and Moeller, Schlingemann, and Stulz (2007)). As with the proxy for industry growth, we use the long-term growth forecast and measure its dispersion. However, the dispersion in long-term growth forecasts for a firm is positively correlated with the mean value of the forecast. To purge the effect of the mean value of the long-term growth forecast (which is likely associated with uncertainty), we use standardized dispersion in analyst earnings growth forecasts aggregated at the industry-level - the dispersion in analyst long-term earnings growth forecasts divided by the absolute value of the mean long-term growth forecast averaged (using value-weighting) at the industry level in the month prior to the IPO - as a proxy for industry-level divergence of opinion. We denote this variable by IDISP.

The first advantage of using an industry-level growth proxy is that it circumvents the need of identifying comparable firms - an often noisy process, as is done in Kim and Ritter (1999). Moreover, instead of relying on specific valuation multiples, all we require is that the industry-level growth is correlated with the IPO firm's growth. Valuation metrics are endogenous to investor reaction since these metrics use a market price which may already reflect investors' reactions to growth prospects. This means that we can unambiguously test investor reaction to growth prospects using industry earnings growth rate, but we cannot do so using valuation metrics which suffer from a joint hypothesis problem - representing both growth prospects and investor reaction. Therefore, our approach tremendously reduces misspecification problems both in identifying comparable firms and in specifying valuation metrics.

A second advantage of using an ex ante measure of growth prospects (IGROW) and divergence of opinion (IDISP) is that we can test the causal relationship between growth

growth measures. All of our results are qualitatively unaffected if we use equal weighing in forming industry growth measures. 
prospects (and heterogeneous beliefs) and IPO stock performance. Rajan and Servaes (1997) find evidence that investors overreact to post-IPO firm-level analyst long-term forecasts in a sample of IPOs during 1975-1987. In addition, past studies testing the Miller effect on IPOs also use ex post measures which rely on information available only after the IPO issuance and therefore are not able to examine the impact of investor heterogeneity on first-day returns. The information right after the IPO may reflect investor reaction to the offer price and first-day returns, in addition to the uncertainty of the IPO. Therefore, these studies can at best offer a partial test of the investor misreaction or the Miller (1977) prediction about asset valuation.

A third advantage of using an industry-level analyst forecast measure is that we can more clearly identify the economic source of potential IPO misvaluation, if we find a significant association between such a measure and IPO stock performance. As discussed above, this line of reasoning highlights the role of limited attention, investor categorizing, and overconfidence that is being documented in the finance literature.

Another advantage of our approach is that we can maximize the sample size and offer the most general test for our hypotheses, because we do not rely on the accounting items for computing an intrinsic value of the IPO as in Purnanandam and Swaminathan (2004) and Chemmanur and Krishnan (2009). Our IPO sample size each year more than doubles that of comparable studies (e.g., Purnanandam and Swaminathan (2004)).

\subsection{Summary of Theory Predictions}

Aggregating the theories about the effects of industry growth on short-run and long-run returns, we can summary the empirical predictions as follows: 


\begin{tabular}{|l|c|c|}
\hline & \multicolumn{2}{|c|}{ Effect of industry growth (IGROW) on } \\
\hline Hypothesis & Short-run return & Long-run return \\
\hline Information asymmetry/risk & + & 0 \\
\hline Underreaction & + & + \\
\hline Overreaction & + & - \\
\hline
\end{tabular}

These hypotheses are not necessarily mutually exclusive. For example, the information asymmetry effect could lead to a positive relation between industry growth and the short-run price, but the under- or overreaction effects can cause a relation between industry growth and long-run performance. In addition, investors may react to the same type of information about earnings growth differently during different periods, depending on factors such as stock market conditions or technological advances. It is possible that underreaction is exhibited in certain periods and overreaction exhibited in others times. In our empirical test, we control for the effect of divergence of opinion by including our proxy of belief dispersion (IDISP) as a control variable in multivariate tests. Finally, we will examine the effect of industry growth on the decision to withdraw an IPO as a supplementary test to the industry growth effects on IPO performance.

\section{Data and Summary Statistics}

\subsection{Data}

We obtain data on IPOs of ordinary common shares from 1982 to 2007 from the Securities Data Company (SDC). ${ }^{3}$ We eliminate 558 IPOs that are not covered by the Center for Research in Security Prices (CRSP) within one month of the offering, and 766 IPOs with an offer price less than $\$ 5$, leaving 9,066 observations. Additionally, we eliminate 2 IPOs for which our

\footnotetext{
${ }^{3}$ We begin ours sample in 1982 because analyst earnings growth forecasts from IBES are only become available in that year. We end our sample in 2007 to allow for a 3 year window to calculate long-run returns.
} 
variable of interest, average industry analyst earnings growth forecasts, is missing, leaving 9,064 observations (the "broad" sample). Finally, after removing unit offerings, closed-end funds, American Depository Receipts (ADRs), Real Estate Investment Trusts (REITs), and Shares of Beneficial Interest (SBIs), we have 7,608 IPOs in the "full sample".

We examine the bubble period (01/1999-12/2000) observations separately, for several reasons. First, investors may react to information such as industry growth prospects differently in the bubble period, influenced by bubble period hype on Internet or technology in general, as often pointed out by commentators. Second, there is evidence that underwriters may have a change in their objective functions in the late 1990s (Loughran and Ritter (2004)). Third, Ritter and Welch (2002) document that standard Fama-French risk adjustment methodology can produce very odd long-run return results for Internet bubble IPOs. We therefore divide our sample into three periods: pre-bubble (5,906 IPOs), bubble (824 IPOs), and post-bubble (878 IPOs).

We obtain company founding dates and Carter and Manaster (1990) underwriter reputation rankings updated by Professor Jay Ritter. ${ }^{4}$ Share prices, returns, share codes and shares outstanding are obtained from CRSP and accounting data are from Compustat. Industry classifications, ${ }^{5}$ industry returns, and Fama and French (1993) factors are obtained from Professor Kenneth French's website. ${ }^{6}$ Analyst earnings forecasts are taken from I/B/E/S. Finally, we obtain the Lyandres et al. (2008) investment factor from the authors.

\subsection{Summary Statistics of IPOs}

Table 1 reports summary statistics for variables used throughout this paper. Panel A reports industry and firm-level long-term analyst earnings forecasts. The first variable, our

\footnotetext{
${ }^{4} \mathrm{http} / / /$ bear.cba.ufl.edu/ritter/ipodata.htm

${ }^{5}$ We augment the Fama-French 49-industry classification with an Internet industry to create a 50-industry classification. Specifically, we reclassify firms which are classified as Internet firms according to Professor Jay R. Ritter's list of Internet IPOs into a $50^{\text {th }}$ industry. Additionally, we move SIC code 8731 from Business Services to Pharmaceuticals similar to Edelen and Kadlec (2005).

${ }^{6} \mathrm{http}: / / \mathrm{mba}$.tuck.dartmouth.edu/pages/faculty/ken.french/data_library.html
} 
measure of growth prospects, is the value-weighted industry-average mean analyst long-term earnings growth forecast (IGROW). It has a mean (median) of $18.16 \%(16.09 \%)$. The second variable, IDISP, is the industry-level standard deviation of analyst long-term earnings growth forecasts scaled by the absolute value of the mean analyst long-term forecast, value-weighted across all firms in the IPO firm's industry in the month prior to the offer. ${ }^{7}$ Since the mean and standard deviation of the long-term earnings growth forecasts are $69.5 \%$ correlated, and our goal is to capture divergence of opinion and not earnings growth, we standardize dispersion of analyst forecasts by the absolute value of mean analyst forecasts to form our measure of belief dispersion (IDISP). It has a mean of $22.38 \%$, with a median of $20.18 \%$. We also gather firm-level long-term growth forecasts and their standard deviation for IPOs when they are first available in the year after the offer. The firm-level long-term growth forecast is on average lower than its industrylevel equivalent (29.9\% at the firm-level versus $18.2 \%$ at the industry-level), however the two are still highly correlated (50.0\%).

Firm age, defined as the number of years between the IPO and the year the firm was founded, is 16.07 years on average (8 years in median). This is similar to Ljungqvist and Wilhelm (2005) who find an average age of 14.4 years, albeit on a much shorter sample period, and also to Loughran and Ritter (2004) who find a median age of 7 years over the same sample period. Other variables have similar values to those found in the literature.

Panel B reports market characteristics. We use two measures of short-run price performance. The first is the price adjustment of the offer price (PRADJ), defined as the percentage change in price from the file price to the offer price. It has a mean (median) of $-0.27 \%$ (0). The second short-run performance measure is the first-day return (FDRET), defined as the percentage increase in the first trading day closing market price from the offer price. It is $17.44 \%$ in mean (6.25\% in median), similar to Loughran and Ritter (2004) who study the same time

\footnotetext{
${ }^{7}$ Although unreported, the mean (median) standard deviation of long-term growth forecasts of $5.02 \%$ (4.24\%) is similar to the numbers in Moeller et al. (2007).
} 
period and find a mean first-day return of $18.7 \%(6.3 \%$ in median $){ }^{8}$ We examine long-run performance over the first three years after the IPO. We calculate buy-and-hold returns using daily returns from the beginning of the holding period until the end of the holding period or the delisting date, whichever is earlier. Style-adjusted buy-and-hold abnormal returns (BHARs) are calculated as the difference between the IPO's buy-and-hold return and the buy-and-hold return from an equal-weighted portfolio matched on size and book-to-market. BHARs are very close to zero for each of the three horizons.

In Table 2, yearly means are provided for the main variables used throughout this paper. The annual number of IPOs is consistent with prior literature such as Loughran and Ritter (2004). Figure 1 plots the monthly distribution of IGROW, FDRET and number of IPOs to get a better picture of the time-series variation in the industry growth measure. Interestingly, both industry growth and first-day return peak in the bubble period, while the number of IPOs peaks before the bubble period. There is a dramatic decrease in IPO activity and FDRET after the burst of the Internet bubble in 2000. IGROW decreases in the late 1980s and increases throughout the 1990s reaching a peak in the year 2000, after which their values yet again decline. Unlike industry growth, the measure of divergence of opinion, IDISP, peaks in the late 1980s and in the 2000s. This indicates that industry growth has a much stronger association with the extreme first-day returns of the bubble period (1999-2000) than divergence of opinion does.

Overall, for all IPOs in our sample, the mean equal-weighted 1-year, 2-year, and 3-year BHARs are $-0.06 \%, 6.5 \%$, and $5.3 \%$, respectively (not significantly different from zero based on t-statistics); in periods outside of the bubble, they actually earn statistically positive abnormal returns. This indicates that there is no general underperformance in the long-run returns of IPOs. However, in the bubble period, IPOs substantially underperform in the long-run, consistent with the conclusion from the media press.

\footnotetext{
8 Loughran and Ritter exclude Banks and Savings \& Loans and supplement their data with data from Dealogic and other sources, while we do not.
} 
We sort the sample firms yearly into 3 portfolios based on IGROW, and examine the portfolio characteristics of IPOs with low, medium and high IGROW in Table 3. To control for the time pattern in IGROW, we sort the sample firms monthly into 3 portfolios based on IGROW. Table 3 examines the differences in industry growth, analyst dispersion, and firm and offer characteristics between high and low IGROW portfolios, for the full sample as well as for the non-bubble and bubble periods separately.

Overall, high IGROW IPOs tend to be smaller (with lower expected proceeds) and younger growth firms. However, there are noticeable differences across the IGROW portfolios between the non-bubble and bubble periods. For example, the spread in IGROW between the high and low IGROW portfolios is much larger for the bubble period than for the non-bubble periods; the analyst dispersion measure (IDISP) is negatively correlated with IGROW in the prebubble period, but the relationship is weaker in the bubble period and insignificant post-bubble; firms are younger and have higher expected proceeds in the bubble period; and the proportion of technology firms or Internet firms is much higher in the bubble period. In fact, during the bubble period, 97\% (93\%) of IPOs in the high IGROW portfolio are Internet (technology) IPOs.

What these data tell us is that many variables such as IGROW, TECH, and INTERNET are highly correlated, especially in the bubble period. The differences between the three periods also suggest that, in assessing the economic impact of these variables on IPO performance, we should use the characteristics (such as standard deviation) for each period separately.

\section{Cross-Sectional Short- and Long-Run Performances}

In this section, we first present short-run and long-run return results for univariate portfolios sorted by industry growth (IGROW). We first look at results for the full sample, followed by the separate "non-bubble" period (1982-1998 and 2001-2006) and the "bubble" period (1999-2000) results. We then present results for event-time multivariate regression tests where we control for multiple factors including the divergence of opinion variable (IDISP). 


\subsection{Univariate Tests}

As a first look at the effect of industry analyst dispersion on IPO market performance, Table 4 reports univariate sorts of cumulative style-adjusted buy-and-hold returns into terciles based on low, mid and high IGROW, for the full sample. Equal-weighted portfolios are reported in Panel A, while Panel B reports value-weighted portfolios. We measure short-run market performance by two variables: the offer price adjustment (PRADJ), and the first-day return (FDRET). We measure the long-run performance by style-adjusted buy-and-hold returns (BHARs), defined as the difference between the IPO's buy-and-hold returns and the buy-andhold return from an equal-weighted portfolio matched on size and book-to-market $(5 \times 5$ benchmark portfolios). The t-statistics for equality of means are based on simple two-sample test statistics computed under the assumption of independence. Empirical p-values are also reported since the sample distribution of BHARs tends to be misspecified in event studies, especially for long-run returns. ${ }^{9}$ We present results for the pre-bubble, bubble, and post-bubble periods, respectively, in Tables 4-6.

Tables 4 and 5 show a positive relation between IGROW and short-run performance (measured by PRADJ and FDRET), for both the pre-bubble and especially the bubble period. However, the effect of IGROW on long-run performance is fundamentally different between the two periods.

Table 4 shows that in the pre-bubble period, there is a strong positive relation between IGROW and long-run abnormal stock performance, which suggests that investors underreact to industry growth prospects at the time of the offer and in the years after the offer. For example, high IGROW IPOs have a mean 2-year equal-weighted BHAR of $60.8 \%$, compared to a $-3.8 \%$ mean BHAR for the low IGROW portfolio. Therefore, buying high IGROW IPOs is on average

\footnotetext{
${ }^{9}$ See Purnanandam and Swaminathan (2004, p. 829) for a description of this procedure. Briefly, using empirical p-values preserves the skewness, time-series autocorrelation and cross-sectional properties of the original sample, all of which are at the root of the misspecification of long-run returns.
} 
profitable in the non-bubble period, yielding a 2-year mean BHAR that is $64.6 \%$ higher than buying low IGROW IPOs, and the difference is highly significant, judging by the t-statistics or empirical p-value. The Panel B results of value-weighted returns are even starker. Specifically, high IGROW IPOs have 191.2\% higher mean 2-year value-weighted BHAR than low IGROW IPOs. This result indicates that the effect of industry growth on IPO performance is not driven by small firms. In fact, the industry effect is much stronger for large IPOs. ${ }^{10}$

Table 5 indicates that during the Internet bubble period, IGROW has an even stronger positive effect on short-run performance than that in the non-bubble period. For example, the high IGROW portfolio has a mean equal-weighted (valued-weighted) FDRET of $89.8 \%(182.5 \%)$. As seen from Table 3 Panel B, this portfolio contains almost entirely Internet IPOs. At the same time, these IPOs earn substantially lower abnormal returns in the 3 years after the offer. For example, the high IGROW firms earn 51.6\% (65.8\%) lower 2-year abnormal returns than low IGROW firms. These results suggest that during the bubble period, investors are overoptimistic about the growth prospects of certain high growth industries and bid up the short-run price too high, leading to a poor performance in the long run. In spirit, this result is consistent with the findings of Ritter and Welch (2002) and Loughran and Ritter (2004) who suggests that certain economic forces and investor behaviors during the bubble period are different from other periods.

Table 6 shows that in the post-bubble period, the association between industry growth and IPO performance (both short-run and long-run) becomes much weaker. There is some evidence of a positive relation between IGROW and FDRET, and negative relation between IGROW and 2-year BHAR, but these relations are not robustly significant, and vanish when returns are value-weighted.

Figures 2-4 provide a graphical summary of the portfolio tests. Figure 2 shows the equalweighted short-run and long-run market performances separately for the pre-bubble, bubble, and

\footnotetext{
${ }^{10}$ In untabulated tests, we find that the positive effect of IGROW on long-run returns exists almost entirely in the 1990s; the effect is insignificant in the 1980s. One possible reason is that the analyst long-term earnings forecasts are relatively sparse and noisy in the earlier years.
} 
post-bubble periods. Figure 3 shows the same pattern for the value-weighed returns, with even striking magnitude of both the short- and long-run effects of industry growth. Figure 4 plots the high-low IGROW hedge profits for the three periods, to highlight the differential effects of IGROW on IPO stock performance during the different periods.

During the non-bubble years, the average portfolios returns are all positive for the high IGROW portfolios, and closer to zero for the low IGROW portfolios. This result suggests that the divergence of opinion theory of Miller (1977) is unlikely to have a dominant effect on the stock performance during the non-bubble periods. The bubble-period pattern - short-run overreaction and long-run underperformance - could be a result of investor overreaction to industry growth or a result of the divergence of opinion. We address this topic further in the multivariate tests.

\subsection{Multivariate Tests}

We now turn to the cross-sectional analysis of short-run return measures and long-run risk-adjusted returns in order to determine whether the effects of industry growth on IPO stock performance hold in a multivariate setting.

We test the cross-sectional relationship between industry growth and IPO returns in multivariate regressions of the following form:

$$
\begin{aligned}
\text { FDRET }_{i} & =b_{0}+b_{1} \text { IGROW }_{i}+b_{2} \text { IDISP }+b_{3} \operatorname{Ln}\left(1+A G E_{i}\right)+b_{4} \text { UWREP }_{i}+b_{5} \operatorname{Ln}(N M G R)_{i} \\
& +b_{6} \text { VENTURE }_{i}+b_{7} \operatorname{Ln}\left(E P R O C E E D S_{i}\right)+b_{8} \text { TECH }_{i}+u_{i}
\end{aligned}
$$

The dependent variables for our short-run return regressions are the offer price adjustment (PRADJ) and the first-day return (FDRET), respectively. In the independent variable list, we include IDISP to control for any divergence of opinion effect. We include underwriter quality measures (UWREP and NMGR), because Dong, Michel, and Pandes (2011) find they affect long-run IPO performance. UWREP is the average Carer and Manaster (1990) underwriter 
rating of all lead underwriters in the IPO. Ln(NMGR) is the natural logarithm of the number of managing underwriters in the underwriting syndicate. AGE is the number of years between a firm's founding year and the year of its IPO. VENTURE equals one when the IPO is backed by a venture capital firm, and zero otherwise. TECH equals one when the IPO is in a high-tech industry, and zero otherwise. EPROCEEDS is the expected offer proceeds defined as the product of file price and number of file shares. This variable is ex ante relative to all dependent variable include PRADJ.

For long-run return regressions where the dependent variables are 1-year, 2-year, or 3year BHAR, respectively, we also include BV/MV in the regression. MV is the number of shares outstanding times the close price on the first day of trading. BV/MV is the book value of equity after the offer divided by the market value of equity. We run regressions separately for the prebubble, bubble, and post-bubble periods.

Short-run return regression results are reported in Table 7, while long-run return regression results are reported in Table 8 . In Table 7, the positive and significant coefficients of IGROW in the PRADJ and FDRET regressions for the pre-bubble and bubble periods confirm the univariate finding that industry growth is positively associated with short-run price effects, with stronger effects for the bubble period. Noticing the sharp difference in IPO characteristics between different periods (Table 3), we assess the economic impact of the characteristics on IPO returns using data for these periods separately. For example, a one standard deviation increase in IGROW leads to a $3.5 \%(=0.65 \times 5.45$, where $5.45 \%$ is the standard deviation of IGROW during the pre-bubble period) increase in FDRET in the pre-bubble period. The corresponding effect during the bubble period is a much higher $22.3 \%(2.21 \times 10.09)$. There is no significant relation between IGROW and short-run performance post-bubble. The Appendix Table provides a summary of the economic impact of each variable on the short-run and long-run performances for the three sample periods. 
In Table 8, the coefficients of IGROW in the long-run return regressions indicate that the effect of industry growth on long-run IPO performance flips from positive for the pre-bubble period to negative for the bubble period, confirming the finding from univariate portfolio sorts. Interestingly, the proxy for divergence of opinion (IDISP) shows up insignificantly in the prebubble regressions. This result suggests that the dispersion of investor belief about industry growth is unlikely to be a general force in explaining IPO performance, once industry growth itself is taken into account. However, there does appear to be a negative association between IDISP and BHAR in the bubble and post-bubble periods, which is consistent with some limited role of the Miller (1977) effect on IPO performance.

During the pre-bubble period, underwriter rating (UWREP) and the number of managing underwriters (NGMR) both have a positive effect on long-run performance, consistent with Dong et al. (2011). We also find that the expected proceeds (EPROCEEDS) has a significant and negative effect on long-run returns. Note that EPROCEEDS has a negative effect on short-run returns (Table 7), which could indicate either a dilution effect of the offer on share price or issuers offering more shares when they believe the valuation is high. The strong and negative coefficient of EPROCEEDS on long-run returns is more consistent with a market timing interpretation, because dilution should not have a long-run effect on price. ${ }^{11}$

In terms of economic significance, a one standard deviation increase in IGROW leads to a $51.1 \%$ increase in 3-year BHAR during the pre-bubble period. This is larger than the impact of any other factor considered; in descending order, the corresponding absolute values of the impact of other significant factors are: $40.0 \%$ for UWREP, $29.0 \%$ for $\operatorname{Ln}($ EPROCEEDS), and $19.8 \%$ for Ln(NMGR).

In the bubble period, the two most significant variables for long-run BHARs are IGROW and $\operatorname{Ln}(1+\mathrm{AGE})$. IGROW attains the greatest statistical and economic significance levels for the

\footnotetext{
${ }^{11}$ In untabulated tests, when we replace EPROCEEDS with actual proceeds (PROCEEDS $=$ offer price $\times$ number of shares offered), all of our main results remain unaffected, but PROCEEDS becomes significantly negative (at the $10 \%$ level) for the 1-year BHAR for the bubble period.
} 
BHARs. This result suggests that in the bubble years, investors are overoptimistic about IPOs in general, but especially about IPOs in high growth industries with young ages. In terms of economic significance, a one standard deviation increase in IGROW leads to a $19.3 \%$ drop in 3 year BHAR, compared to a corresponding impact of $17.5 \%$ for $\operatorname{Ln}(1+\mathrm{AGE})$.

In the post-bubble period, there is a much reduced IPO activity, and IGROW and IDISP are the only two variables that have some ability to explain long-run performance. It appears that the negative effect of IGROW on BHAR lingers for up to two years after the IPO. Also, the effect of belief dispersion remains also for two years after the offer.

One possible explanation of the effects we document is that the relation between IGROW and BHARs reflect an industry growth effect on stock returns in general. Does the effect of IGROW on long-run IPO returns arise from a market-wide industry effect? In untabulated tests, we examine the effect of IGROW on long-run abnormal returns, where the abnormal returns are industry-adjusted, using the 50 industry returns as the benchmark returns. The effect of IGROW on long-run performance remains almost unchanged for the pre-bubble period, with somewhat reduced significance for the bubble and post-bubble periods. These results indicate that the IGROW effect on IPO performance is distinct from a general market-wide industry effect.

\section{Calendar-Time Long-Run Performance}

The evidence we have presented up to now shows that industry growth rate positively (negatively) predicts IPOs stock returns in the 3 years following the IPO, for the pre-bubble (bubble) periods, respectively. There is also some weak evidence of a negative effect of IGROW on 1-year and 2-year BHARs in the post-bubble period. In this section, we report calendar-time risk-adjusted performance of high, medium and low industry growth portfolios. These tests avoid the autocorrelation problems present in overlapping returns and account for cross-correlation among returns across clustered events. On the other hand, the power to detect abnormal performance when it is present tends to be lower than other tests (Loughran and Ritter (2000)). 
We conduct calendar-time tests mainly for the robustness of our results. We examine these performance measures over the first three years after the IPO.

Calendar-time factor-adjusted returns are obtained using LSZ (2008) plus Carhart's (1997) momentum factor (five-factor) regressions involving the monthly calendar time returns of IPO portfolios. IPOs can remain in the sample for a 3-year period after which time they drop out. More specifically, IPOs are assigned to a high, medium, or low IGROW monthly portfolio starting the second calendar month after the IPO. The IPOs stay in the sample for up to 3 years, but the portfolios are rebalanced monthly. The factor-adjusted return is the intercept from this regression. The Pre-Bubble, Bubble, and Post-Bubble periods include IPOs from 1982 to 1998, 1999 to 2000 , and 2001 to 2007 , respectively. Returns for the three periods are taken between 1983 and 1999 (204 observations), 2000 and 2001 (24 observations), and 2002 and 2008 (84 observations), respectively, to maintain sufficient firms in each portfolio.

Table 9 reports the intercepts of the calendar-time regressions, which can be interpreted as the risk-adjusted monthly abnormal returns for the 3-year holding period. Panel A reports results for equal-weighted portfolios, while Panel B shows results for value-weighted portfolios. In Panel A, for the pre-bubble period, the intercept for the high minus low industry growth zeroinvestment portfolio is $0.67 \%$ (significant at the $1 \%$ level), indicating that the high IGROW portfolio outperforms the low IGROW portfolio by about $24 \%(0.67 \times 36)$ over a 3 -year period. Looking at the individual portfolios, we can see that the high minus low hedge profits arise from the underperformance of the low and mid IGROW portfolios rather than from the outperformance of the high IGROW portfolio.

In Panel B, the high minus low IGROW hedge portfolio profit is larger in magnitude for value-weighted portfolios than equal-weighted portfolios. The high industry growth portfolio earns about $43 \%(1.19 \times 36)$ more than the low industry growth portfolio. Also, the intercept of the high IGROW portfolio shows a significant abnormal return of $29 \%$ over a 3 -year period. This finding again suggests that this effect is not driven by small IPOs. 
Ritter and Welch (2002) find calendar-time test for the bubble period is sensitive to the months chosen. We realize that calendar-time regression may not be appropriate for the bubble period, but present this test anyway for completeness. Despite the large magnitude of the industry growth effect on long-run returns, calendar-time regressions only show a marginally significant (at the 10\% level) high minus low IGROW hedge profit for equal-weighted portfolios. To the extent that the high minus low IGROW hedge portfolio returns are highly negative, with point estimates much larger in magnitude than those for the pre-bubble period, the evidence is still in line with the event-time tests documented in Section 4. However, when returns are valueweighted, we observe a significant and negative abnormal performance of the high IGROW portfolio, consistent with the event-time evidence. This is quite remarkable in light of the Ritter and Welch (2002) finding that the calendar-time regressions are rather unreliable for the bubble period.

Finally, the pre-bubble period regression intercepts are all insignificantly different from zero for both the equal and value-weighted portfolios, adding to the event-time evidence that the negative relation between IGROW and long-run performance is not robust.

\section{IPO Withdrawal}

We have documented the effect of industry growth prospects on stock performance. It appears that in the most recent period, industry growth has a rather weak effect on IPO performance compared to previous periods. It is possible that with the burst of the Internet bubble, investors have a "bad taste in the mouth" for high-IGROW IPOs which were in favor during the Internet bubble. If so, firms in high growth industries that originally intend to go public may be discouraged by the downward shift in investor sentiment and withdraw the IPO. We therefore examine the relation between industry growth and IPO withdrawal.

Table 10 reports univariate test results. In the pre-bubble period, high IGROW firms tend to have a better chance to complete the IPO, as seen from the statistically significant and positive 
difference of $1.05 \%$ in IGROW between completed and withdrawal IPOs. This pattern is much stronger during the bubble period, which sees a corresponding difference of $8.59 \%$ between the two groups. In contrast, post-bubble, this difference becomes a statistically significant and negative value of $-2.32 \%$, suggesting that IPOs in high growth industries are more likely to withdraw after the bubble.

These patterns are confirmed in the logistic regressions in Table 11. In both the prebubble and bubble periods, IGROW has a significantly negative effect on the probability of withdrawal, which suggests that IPOs in high growth industries are less likely to withdraw. This relation reverses in the post-bubble period, so that IPOs in high growth industries are more likely to withdraw. This finding provides supplementary evidence for the conclusion that investors tend to shun high growth industries after the dismal performance of IPOs in "high growth" industries during the Internet bubble.

The significant effect of IGROW on IPO withdrawal raises the possibility of sample selection bias: completed IPOs may be selected by the market based on their industry growth prospects. In untabulated tests, we control for possible selection bias using the Heckman's (1979) two-stage procedure. None of our results is materially affected by this procedure. We conclude that the effects of industry growth on IPO performance is not driven by sample selection bias.

\section{Discussion}

The information asymmetry or risk hypothesis may play a role for the short-run price effect, but it cannot explain the long-run evidence. The strong association between industry growth and long-run IPO performance suggests that IPO participants do not fully understand the information content of industry growth prospects. The evidence points to an investor tendency to underreact to growth prospects in normal times, and a tendency to overreact to the same information during the bubble period. 
The empirical results show that our industry earnings growth rate measure, constructed by aggregating analyst long-term earnings forecasts at the industry level, has a substantial effect on IPO stock performance. In normal times, this industry growth measure positively predicts long-run IPO performance, suggesting that while analyst long-term forecasts may be subject to biases (e.g., La Porta (1996)), these forecasts do provide useful information about an industry's growth potential.

Rajan and Servaes (1997) document that IPO investors tend to be misled by analysts, so that they are overoptimistic about IPO firms' growth prospects. A major difference between our study and theirs is that we use an ex ante proxy for IPO growth. As discussed in Section 2, it is important to use an ex ante measure because ex post analyst forecasts may be the result, rather than the cause, of IPO initial performance. Also, we need both the short-run and long-run effects of industry growth prospects to distinguish hypotheses.

While the evidence during and after the bubble shows some effect of divergence of opinion on long-run returns, the finding that the divergence of opinion hypothesis does not explain IPO stock performance for the pre-bubble period (77.6\% of the observations) may be somewhat surprising, especially given that the prior literature on the Miller (1977) hypothesis often finds support of this theory. We discuss this finding below.

A body of literature has emerged that challenges the efficiency of the market in setting the aftermarket price: instead of the offer price being set low by the underwriters or issuer, it is possible that the first-day closing price is set too high by market participants. For example, Purnanandam and Swaminathan (2004) document that IPO prices are overvalued relative to intrinsic values, and that more overvalued IPOs tend to underperform both the market and other IPO firms for up to five years after the offer. Using European IPO samples around the bubble period, Derrien (2005), Cornelli, Goldreich and Ljungqvist (2006), and Dorn (2007) find evidence consistent with investors overvaluing IPOs in the short-run and this overvaluation leading to underperformance in the longer-run. 
The Miller (1977) theory of divergence of opinion is often cited to explain the initial price jump and long-run underperformance, which is exemplified by the bubble period IPOs. Empirically, there have been attempts to test the Miller theory. Houge, Loughran, Suchanek, and Yan (2001) use three opening-day proxies for uncertainty or divergence of opinion: the percentage opening spread, time of first trade, and flipping ratio to study first-day and long-run returns; Chemmanur and Krishnan (2009) use aftermarket trading volume and share turnover as proxies for heterogeneous beliefs. Gao, Mao, and Zhong (2006) use aftermarket IPO return volatility to study long-run performance. Miller and Reilly (1987) and Ritter (1984, 1987) use aftermarket trading volume or volatility to study the initial returns. However, all these studies use ex post measures which rely on information available only after the IPO issuance and therefore are not able to examine the impact of investor heterogeneity on first-day returns. The information right after the IPO may reflect investor reaction to the offer price and first-day returns, in addition to (or instead of) the inherent uncertainty of the IPO. In other words, the causation may run from the offer price and first-day returns to aftermarket trading behavior.

In contrast, our measure (IDISP) is an ex ante proxy for the dispersion of belief about industry growth prospects. Furthermore, we control for the mean forecast level (IGROW) in our multivariate tests, which offers a way to isolate the mean growth forecast from the dispersion of growth forecast effects. When we omit IGROW and only include IDISP in the long-run return returns, we find (untabulated) that IDISP has a negative effect on BHARs in the non-bubble periods. This shows that omitting the mean growth variable in the regression may be a partial reason why prior literature mentioned above finds support for the divergence of opinion hypothesis.

One reason that divergence of opinion may not drive IPO performance as the Miller theory predicts is that the Miller theory assumes that investors have unbiased mean assessment about the true value of a stock. In reality, if investors' mean assessment deviates from the fundamental value as a result of overall investor sentiment, as occurred in the bubble period, the 
divergence of opinion effect may be dominated by the mean sentiment effect (see Cen, Lu, and Yang (2011)).

A criticism of IDISP is that it only reflects belief dispersion at the aggregate industry level, and a firm-level divergence of opinion measure may be needed to test the theory. To address this point, we offer the following observations. First, IDISP should be at least positively correlated with the "true" belief dispersion about IPOs. We find that during the bubble period, the 1-year BHAR shows a positive High - Low IDISP spread (untabulated), which is inconsistent with the Miller hypothesis. Second, the overall observation that the mean BHARs in non-bubble periods are positive suggests that the divergence of opinion effect, if any, should be on average dominated by other effects. Furthermore, in untabulated tests, we sort our sample firms into high and low IGROW portfolios based on median IGROW, and find that among IPOs with high IGROW, all portfolios sorted by IDISP (similar to the sorts in Table 5) have positive long-run abnormal returns. Regardless of what measures of belief dispersion we use, the Miller effect should not drive these patterns. Finally, we note that IGROW, also an industry-level measure, dominates IDISP in multivariate regressions in the pre-bubble and bubble periods, reinforcing the conclusion that divergence of opinion seems to be dominated by the industry growth effect.

\section{Conclusion}

Using industry earnings growth forecast as a proxy for IPO growth potential, we document a strong association between industry growth prospects and IPO stock performance. IPOs in high growth industries substantially outperform in the three years after the offer, until the Internet bubble period of 1999-2000, when this relationship reverses. In both the pre-bubble and bubble periods, there is a positive relation between industry growth prospects and short-run price performance. For both the short-run and long-run returns, and for both periods, the industry growth effects are stronger when returns are value-weighted, suggesting that the effects are larger for larger IPOs which presumably are more representative of their industries. 
There is some evidence that the negative relation between industry growth and long-run IPO performance lingers after the Internet bubble, with much reduced magnitude compared to previous periods. Coupled with the finding that the relation between industry growth and IPO withdrawal turns positive after the bubble, this evidence suggests that investors may have a "bad taste in the mouth" for IPOs in high growth industries after the burst of the Internet bubble.

Our results are most consistent with investors' tendency to underreact to growth prospects of the IPO in normal times, and their tendency to overreact to the same information during a pronounced market bubble. The information asymmetry or risk hypothesis may be at work for the short-run price effect, but it cannot explain the long-run evidence. With respect to the investment strategy laid out in the beginning of the paper about social network firms such as Facebook, in light of our findings, these firms could be expected to outperform to the extent that they are in a high growth industry, with the caveat that these firms may be conducting their IPO during a "social network bubble".

The industry growth effect on IPO performance is substantial in economic terms. In fact, we have documented that industry growth is the most significant driver of long-run IPO performance among all the factors that we consider, including underwriter quality measures and offer proceeds. Given the magnitude of the effect of this intuitive measure, further investigation of industry growth prospects may provide insights into other aspects of the IPO process. 


\section{References}

Baker, Malcolm, and Jeffrey Wurgler, 2004, Appearing and Disappearing Dividends: The Link to Catering Incentives, Journal of Financial Economics 73, 271-288.

Baker, Malcolm, and Jeffrey Wurgler, 2007, Investor Sentiment in the Stock Market, Journal of Economic Perspectives 21, 129-151.

Barber, Brad M., and Terrance Odean, 2008, All That Glitters: The Effect of Attention and News on the Buying Behavior of Individual and Institutional Investors, Review of Financial Studies 21, 785-818.

Barberis, Nicholas, and Andrei Shleifer, 2003, Style Investing, Journal of Financial Economics 68, 161-199.

Barberis, Nicholas, Andrei Shleifer, and Robert Vishny, 1998, A model of investor sentiment, Journal of Financial Economics 49, 307-343.

Barberis, Nicholas, Andrei Shleifer, and Jeffrey Wurgler, 2005, Comovement, Journal of Financial Economics 75, 283-317.

Benveniste, Lawrence M., and Paul A. Spindt, 1989, How Investment Bankers Determine the Offer Price and Allocation of New Issues, Journal of Financial Economics 24, 343-361.

Brav, Alon, Christopher Geczy, and Paul A. Gompers, 2000, Is the Abnormal Return Following Equity Issuances Anomalous?, Journal of Financial Economics 56, 209-249.

Brav, Alon, and Paul A. Gompers, 2003, The Role of Lockups in Initial Public Offerings, Review of Financial Studies 16, 1-29.

Carhart, Mark, M., 1997, On Persistence in Mutual Fund Performance, Journal of Finance, 52, $57-82$.

Carter, Richard, Frederick Dark, and Ajai Singh, 1998, Underwriter Reputation, Initial Returns, Carter, Richard, and Steven Manaster, 1990, Initial Public Offerings and Underwriter Reputation, Journal of Finance 45, 1045-1067.

Cen, Ling, Kalok Chan, Sudipto Dasgupta, and Ning Gao, 2010, When the Tail Wags the Dog: Industry Leaders and Cross-Industry Information Diffusion, Working Paper, Hong Kong University of Science and Technology.

Cen, Ling, Hai Lu, and Liyan Yang, 2011, Investor Sentiment, Disagreement and Return Predictability of Ownership Breadth, Working Paper, University of Toronto.

Chemmanur, Thomas J., and Paolo Fulghieri, 1994, Investment Bank Reputation, Information Production, and Financial Intermediation, Journal of Finance 49, 57-79. 
Chemmanur, Thomas, and Karthik Krishnan, 2009, Heterogeneous Beliefs, Short Sales Constraints, and the Economic Role of the Underwriter in IPOs, Working Paper, Boston College.

Cooper, Michael J., Orlin Dimitrov, and P. Raghavendra Rau, 2001, A rose.com by Any Other Name, Journal of Finance 56, 2371-2388.

Cornelli, Francesca, David Goldreich, and Alexander Ljungqvist, 2006, Investor Sentiment and Pre-IPO Markets, Journal of Finance 61, 1187-1216.

Corwin, Shane A., and Jay F. Coughenour, 2007, Limited Attention and the Allocation of Effort in Securities Trading, Journal of Finance, forthcoming.

Daniel, Kent, David Hirshleifer, and Avanidhar Subrahmanyam, 1998, Investor Psychology and Security Market Under- and Over- Reactions, Journal of Finance 53, 1839-1885.

Derrien, Francois, 2005, IPO Pricing in "Hot" Market Conditions: Who Leaves Money on the Table?, Journal of Finance 60, 487-521.

Diether, Karl B., Christopher J. Malloy, and Anna Scherbina, 2002, Differences of opinion and the cross section of stock returns, Journal of Finance 57, 2113-2141.

Dong, Ming, Jean-Sébastien Michel, and J. Ari Pandes, 2011, Underwriter Quality and Long Run IPO Performance, Financial Management, forthcoming.

Dorn, Daniel, 2007, Does Sentiment Drive the Retail Demand for IPOs?, Journal of Fianancial and Quantitative Analysis, forthcoming.

Edelen, Roger M., and Gregory B. Kadlec, 2005, Issuer Surplus and the Partial Adjustment of IPO Prices to Public Information, Journal of Financial Economics 77, 347-373.

Fama, Eugene F., and Kenneth R. French, 1993, Common Risk Factors in the Returns on Stocks and Bonds, Journal of Financial Economics 33, 3-56.

Gao, Yan, Connie X. Mao, and Rui Zhong, 2006, Divergence of Opinion and the Long-Term Performance of Initial Public Offerings, Journal of Financial Research 29, 113-129.

Heckman, James, 1979, Sample Selection Bias as a Specification Error, Econometrica 47, 153161.

Hirshleifer, David, Kewei Hou, Siew Hong Teoh, and Yinglei Zhang, 2004, Do Investors Overvalue Firms with Bloated Balance Sheets?, Journal of Accounting and Economics 38 (1-3), 297-331.

Hirshleifer, David, Sonya Lim, and Siew Hong Teoh, 2008, Driven to Distraction: Extraneous Events and Underreaction to Earnings News, Journal of Finance, forthcoming.

Hirshleifer, David, and Siew Hong Teoh, 2003, Limited Attention, Information Disclosure, and Financial Reporting, Journal of Accounting and Economics 36, 337-386. 
Hong, Harrison, and Jeremy Stein, 1999, A unified theory of underreaction, momentum trading and overreaction in asset markets, Journal of Finance 54, 2143-2184.

Hou, Kewei, 2007, Industry Information Diffusion and the Lead-Lag Effect in Stock Returns, Review of Financial Studies 20, 1113-1138.

Houge, Todd, Tim Loughran, Gerry Suchanek, and Xuemin Yan 2001, Divergence of Opinion, Uncertainty, and the Quality of Initial Public Offerings, Financial Management 30, 5-23.

Kahneman, Daniel, 1973, Attention and Effort (Prentice Hall, New Jersey).

Kim, Moonchul, and Jay R. Ritter, 1999, Valuing IPOs, Journal of Financial Economics, 53, 409-437.

La Porta, Rafael, 1996, Expectations and the Cross-Section of Stock Returns, Journal of Finance, $51,1715-1742$.

Ljungqvist, Alexander, and William J. Wilhelm Jr., 2003, IPO Pricing in the Dot-Com Bubble, Journal of Finance 58, 723-752.

Ljungqvist, Alexander, and William J. Wilhelm Jr., 2005, Does Prospect Theory Explain IPO Market Behavior?, Journal of Finance 60, 1759-1790.

Loughran, Tim, and Jay R. Ritter, 1995, The New Issues Puzzle, Journal of Finance 50, 23-51.

Loughran, Tim, and Jay R. Ritter, 2000, Uniformly Least Powerful Test of Market Efficiency, Journal of Financial Economics 55, 361-390.

Loughran, Tim, and Jay R. Ritter, 2002, Why Don't Issuers Get Upset about Leaving Money on the Table in IPOs?, Review of Financial Studies 15, 413-444.

Loughran, Tim, and Jay Ritter, 2004, Why has IPO Underpricing Changed Over Time?, Financial Management 33, 5-37.

Lyandres, Evgeny, Le Sun, and Lu Zhang, 2008, The New Issues Puzzle: Testing the InvestmentBased Explanation, Review of Financial Studies, 21, 2825-2855.

Miller, Edward M., 1977, Risk, Uncertainty, and Divergence of Opinion, Journal of Finance 32, 1151-1168.

Miller, Robert E., and Frank K. Reilly, 1987, An Examination of Mispricing, Returns, and Uncertainty for Initial Public Offerings, Financial Management 16, 33-38.

Moeller, Sara B., Frederik P. Schlingemann, and Rene M. Stulz, 2007, How do Diversity of Opinion and Information Asymmetry Affect Acquirer Returns?, Review of Financial Studies 20, 2047-2078.

Peng, Lin, and Wei Xiong, 2006, Investor Attention, Overconfidence and Category Learning, Journal of Financial Economics 80, 563-602. 
Purnanandam, Amiyatosh K., and Bhaskaran Swaminathan, 2004, Are IPOs Really Underpriced?, Review of Financial Studies 17, 811-848.

Rajan, Raghuram, and Henri Servaes, 1997, Analyst Following of Initial Public Offerings, Journal of Finance 52, 507-529.

Ritter, Jay R., 1984, The "Hot Issue" Market of 1980, Journal of Business 57, 215-240.

Ritter, Jay R., 1987, The Costs of Going Public, Journal of Financial Economics 19, 269-281.

Ritter, Jay R., 1991, The Long-Run Performance of Initial Public Offerings, Journal of Finance 46, 3-27.

Ritter, Jay R., and Ivo Welch, 2002, A Review of IPO Activity, Pricing, and Allocations, Journal of Finance 57, 1795-1828.

Rock, Kevin, 1986, Why New Issues are Underpriced, Journal of Financial Economics 15, 187 212.

Wang, Tracy, Andrew J. Winton, and Xiaoyun Yu, 2010, Corporate Fraud and Business Conditions: Evidence from IPOs, Journal of Finance, 65, 2255-2292. 


\section{Appendix Table: Economic Impact of Regression Variables on Short- and Long-Run Stock Performances}

This table reports the impact (in percentage terms) of a one standard deviation shift in each variable on the short-run performance (PRADJ and FDRET) and long-run returns (BHARs). Only variables that are statistically significant at the $10 \%$ level or above in the event-time regressions are reported. PRADJ is the percentage increase in the offer price from the file price. FDRET is the percentage increase in the first trading day closing market price from the offer price. Style-adjusted buy-and-hold abnormal returns (BHARs) are calculated as the difference between the IPO's buy-and-hold return and the buy-and-hold return from an equal-weighted portfolio matched on size and book-to-market. IGROW is the average mean analyst long-term earnings growth forecast in the IPO firm's industry in the month prior to the offer. IDISP is the average standard deviation of analyst long-term earnings growth forecasts divided by the absolute value of mean analyst long-term earnings growth forecast in the IPO firm's industry in the month prior to the offer. AGE is the number of years between the IPO date and the company's founding date. UWREP is the average Carter and Manaster (1990) underwriter rating of all lead underwriters in the IPO. NMGR is the number of managing underwriters in the syndicate. VENTURE is equal to 1 when the IPO is VC-backed, and 0 otherwise. EPROCEEDS is the expected amount to be raised in the offering (file price $\times$ file shares) in millions of 2007 dollars. TECH equals 1 if the firm is in a high-tech industry, and 0 otherwise. The sample includes IPOs from 1982 to 2007. The Pre-Bubble, Bubble, and Post-Bubble periods include IPOs from 1982 to 1998, 1999 to 2000 , and 2001 to 2007, respectively.

\begin{tabular}{|c|c|c|c|c|c|c|c|c|c|c|c|c|c|c|c|}
\hline & \multicolumn{6}{|c|}{ Impact on Short-Run Performance } & \multicolumn{9}{|c|}{ Impact on Long-Run Returns (BHARs) } \\
\hline & \multicolumn{2}{|c|}{ Pre-Bubble } & \multicolumn{2}{|c|}{ Bubble } & \multicolumn{2}{|c|}{ Post-Bubble } & \multicolumn{3}{|c|}{ Pre-Bubble } & \multicolumn{3}{|c|}{ Bubble } & \multicolumn{3}{|c|}{ Post-Bubble } \\
\hline & PRADJ & FDRET & PRADJ & FDRET & PRADJ & FDRET & $1-Y r$ & $2-\mathrm{Yr}$ & $3-\mathrm{Yr}$ & $1-\mathrm{Yr}$ & $2-Y r$ & $3-Y r$ & $1-\mathrm{Yr}$ & $2-Y r$ & $3-\mathrm{Yr}$ \\
\hline IGROW & 2.51 & 3.54 & 9.99 & 22.30 & & & 12.48 & 51.56 & 51.12 & -27.34 & -21.29 & -19.27 & -5.71 & -8.57 & \\
\hline IDISP & -0.16 & -0.49 & 1.61 & & & -1.13 & & & & & -11.03 & -12.37 & -6.88 & -10.60 & \\
\hline $\operatorname{Ln}(1+\mathrm{AGE})$ & -0.46 & -1.70 & & & -1.15 & & & & & 10.58 & 17.61 & 17.53 & & & \\
\hline UWREP & 1.87 & 0.46 & 6.92 & 23.09 & 3.36 & 3.02 & 7.11 & 37.14 & 39.97 & & & & & & \\
\hline Ln(NMGR) & 1.97 & 2.00 & & & & & 6.04 & 22.54 & 19.82 & & & & & & \\
\hline VENTURE & & & & & -1.57 & 2.50 & & 11.56 & & & & & & & \\
\hline Ln(EPROCEEDS) & -2.08 & -1.66 & -7.54 & -13.83 & & -2.99 & -3.79 & -25.58 & -29.01 & & & & & & \\
\hline $\mathrm{TECH}$ & & 0.82 & & & -2.09 & & -3.04 & & & 14.48 & & & & & \\
\hline
\end{tabular}




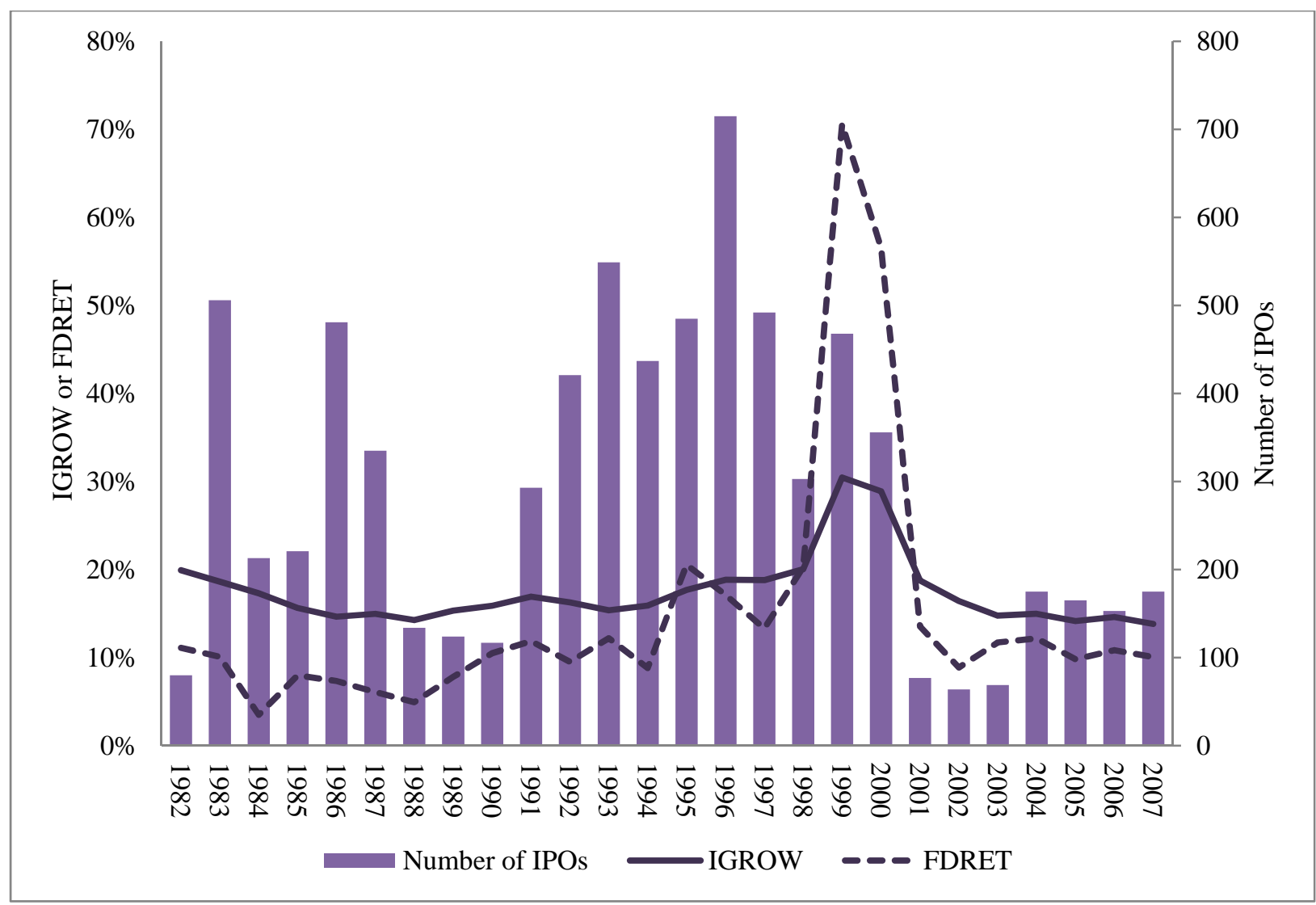

Figure 1: Average Monthly Industry Growth, First-Day Returns and Number of IPOs

This figure plots the average monthly IGROW, FDRET and number of IPOs. IGROW is the average mean analyst long-term earnings growth forecast in the IPO firm's industry in the month prior to the offer. FDRET is the percentage increase in the first trading day closing market price from the offer price. The sample includes IPOs from 1982 to 2007. 
Panel A: Pre-Bubble Period

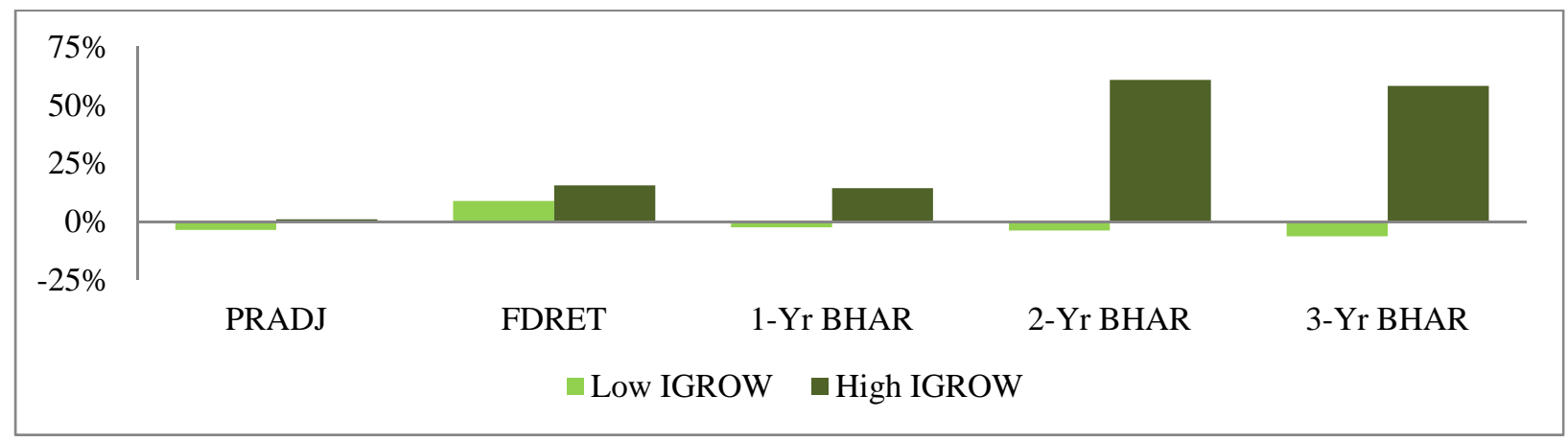

\section{Panel B: Bubble Period}

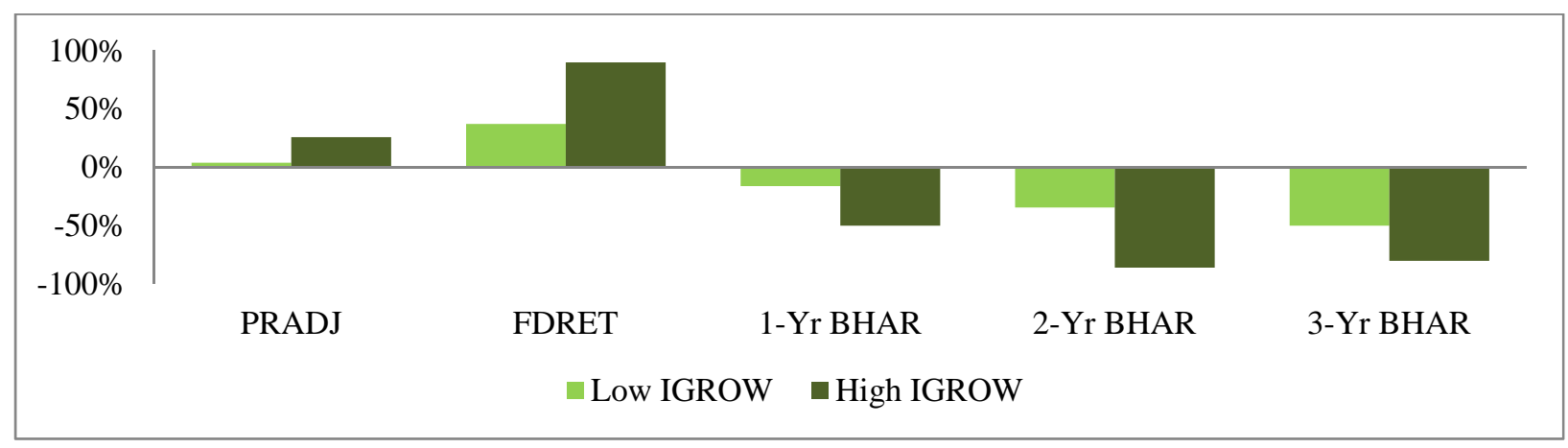

\section{Panel C: Post-Bubble Period}

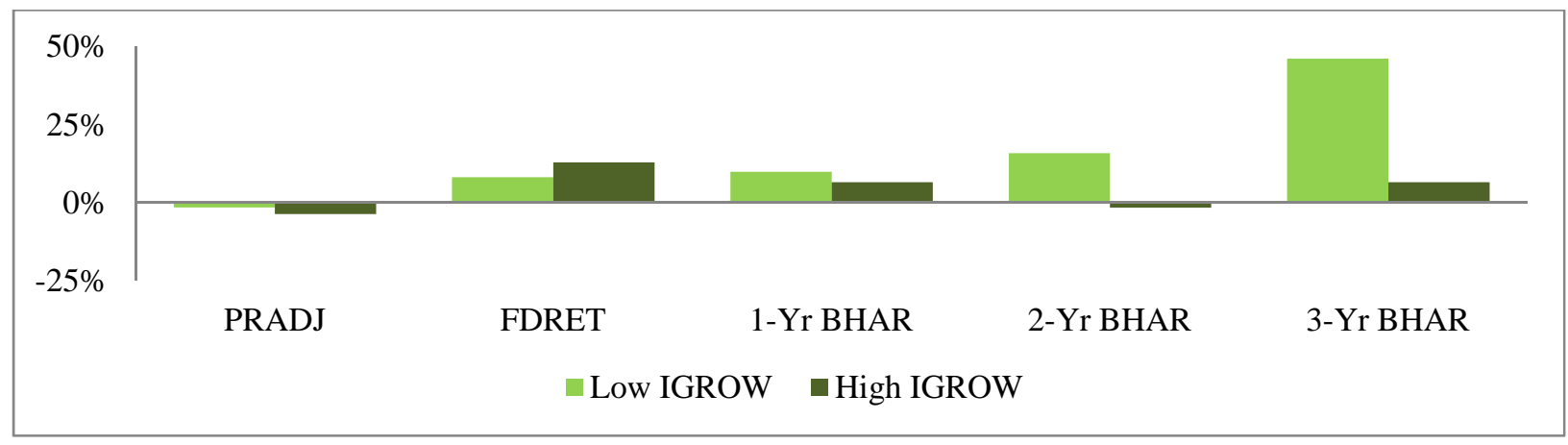

Figure 2: Equal-Weighted Returns of Low and High Industry Growth IPO Portfolios

This figure plots the equal-weighted returns of low and high IGROW portfolios. Panel A examines the Pre-Bubble period, Panel B examines the Bubble period, and Panel C examines the Post-Bubble period. The portfolios are constructed by allocating IPOs to low, medium or high IGROW portfolios as they become public. The IPOs remain in their respective portfolios for up to 3 years after which time they drop out. IGROW is the average mean analyst long-term earnings growth forecast in the IPO firm's industry in the month prior to the offer. PRADJ is the percentage increase in the offer price from the file price. FDRET is the percentage increase in the first trading day closing market price from the offer price. Style-adjusted buy-and-hold abnormal returns (BHARs) are calculated put as the difference between the IPO's buy-and-hold return and the buy-and-hold return from an equal-weighted portfolio matched on size and book-to-market. The sample includes IPOs from 1982 to 2007. The Pre-Bubble, Bubble, and Post-Bubble periods include IPOs from 1982 to 1998, 1999 to 2000, and 2001 to 2007, respectively. 


\section{Panel A: Pre-Bubble Period}

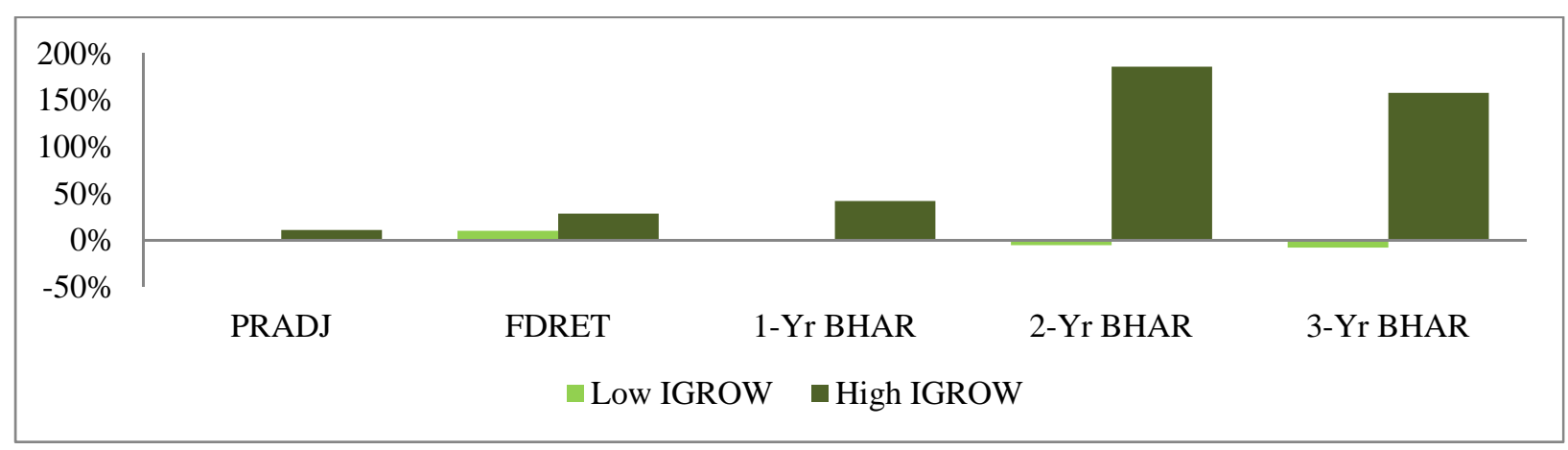

\section{Panel B: Bubble Period}

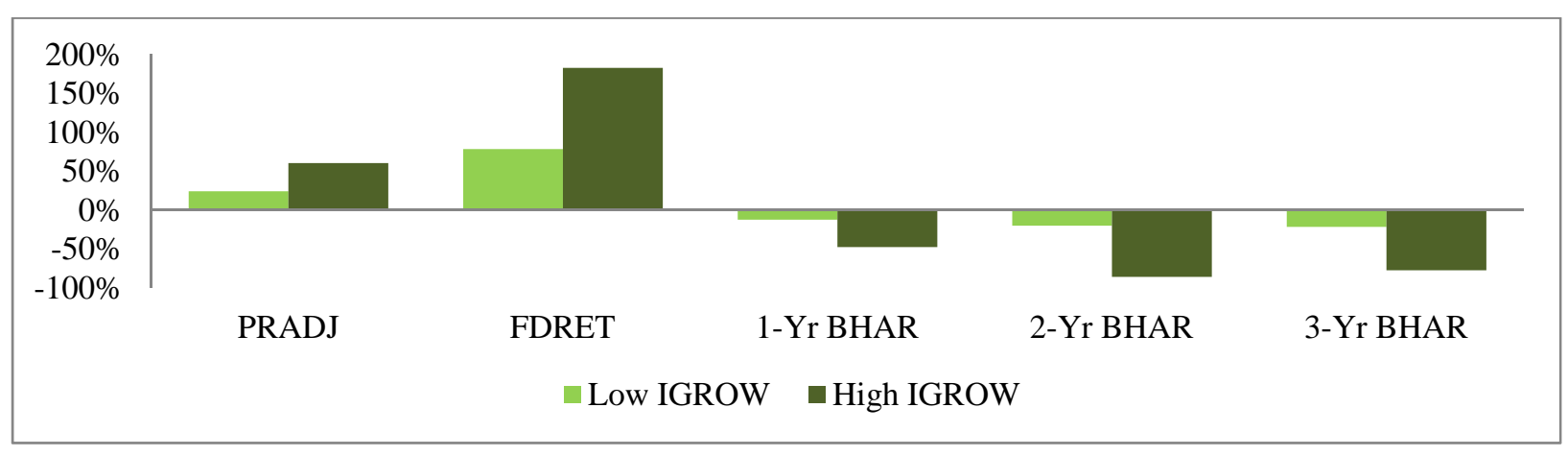

\section{Panel C: Post-Bubble Period}

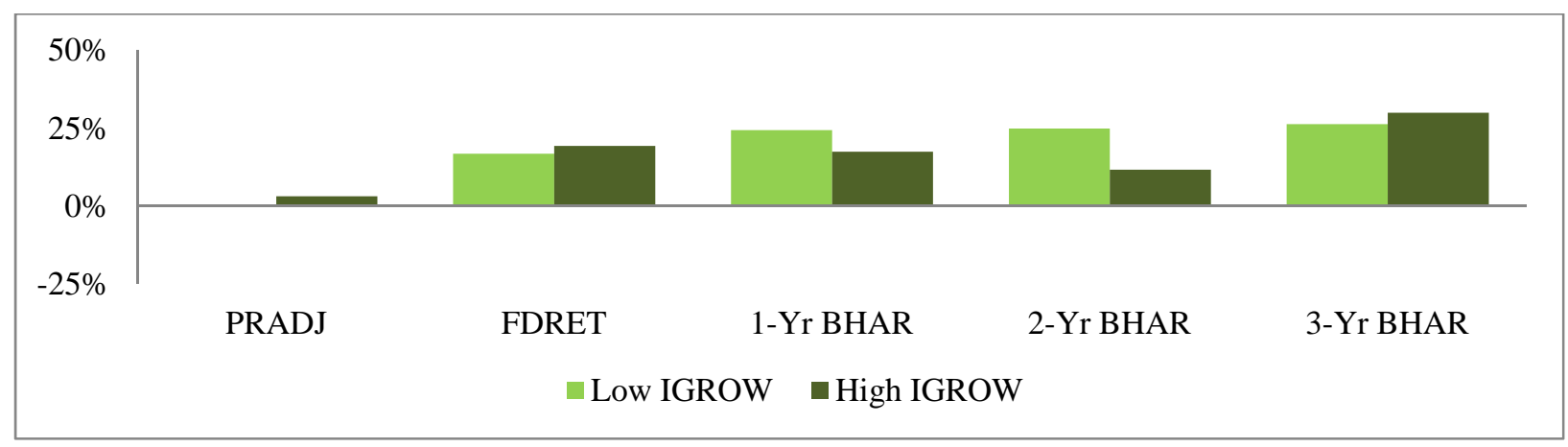

Figure 3: Value-Weighted Returns of Low and High Industry Growth IPO Portfolios

This figure plots the value-weighted returns of low and high IGROW portfolios. Panel A examines the Pre-Bubble period, Panel B examines the Bubble period, and Panel C examines the Post-Bubble period. The portfolios are constructed by allocating IPOs to low, medium or high IGROW portfolios as they become public. The IPOs remain in their respective portfolios for up to 3 years after which time they drop out. IGROW is the average mean analyst long-term earnings growth forecast in the IPO firm's industry in the month prior to the offer. PRADJ is the percentage increase in the offer price from the file price. FDRET is the percentage increase in the first trading day closing market price from the offer price. Style-adjusted buy-and-hold abnormal returns (BHARs) are calculated put as the difference between the IPO's buy-and-hold return and the buy-and-hold return from an equal-weighted portfolio matched on size and book-to-market. The sample includes IPOs from 1982 to 2007. The Pre-Bubble, Bubble, and Post-Bubble periods include IPOs from 1982 to 1998, 1999 to 2000, and 2001 to 2007, respectively. 


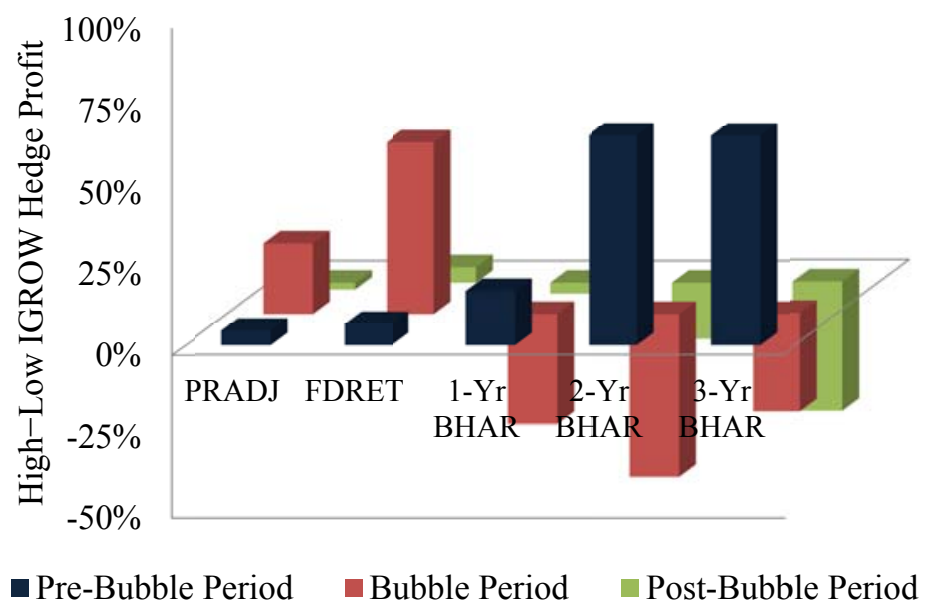

Panel B: Value-Weighted Portfolios

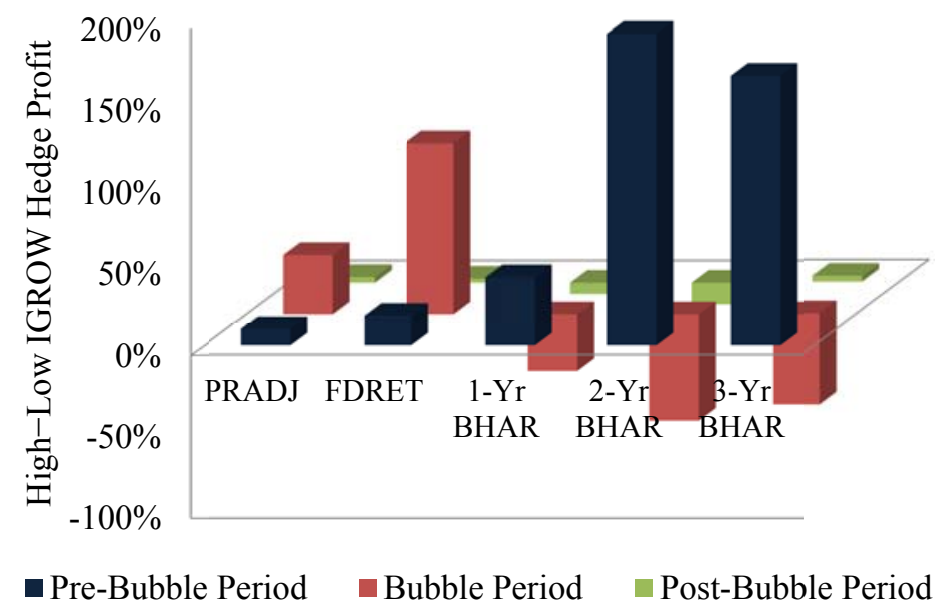

Figure 4: Returns of the High minus Low Industry Growth IPO Hedge Portfolio

This figure plots the returns of the High-Low IGROW hedge portfolio. Panel A examines the equal-weighted portfolio, while Panel B examines the value-weighted portfolio. The portfolios are constructed by allocating IPOs to low, medium or high IGROW portfolios as they become public. The IPOs remain in their respective portfolios for up to 3 years after which time they drop out. IGROW is the average mean analyst long-term earnings growth forecast in the IPO firm's industry in the month prior to the offer. PRADJ is the percentage increase in the offer price from the file price. FDRET is the percentage increase in the first trading day closing market price from the offer price. Style-adjusted buy-and-hold abnormal returns (BHARs) are calculated put as the difference between the IPO's buy-and-hold return and the buy-and-hold return from an equal-weighted portfolio matched on size and book-tomarket. The sample includes IPOs from 1982 to 2007. The Pre-Bubble, Bubble, and Post-Bubble periods include IPOs from 1982 to 1998,1999 to 2000 , and 2001 to 2007 , respectively. 
Table 1: Summary Statistics of Analyst Forecast, Firm, Offer and Market Characteristics: Full Sample

IGROW is the average mean analyst long-term earnings growth forecast in the IPO firm's industry in the month prior to the offer. IDISP is the average standard deviation of analyst long-term earnings growth forecasts divided by the absolute value of mean analyst long-term earnings growth forecast in the IPO firm's industry in the month prior to the offer. TECH equals 1 if the firm is in a high-tech industry, and 0 otherwise. INTERNET is equal to 1 when the IPO is issued by an internet company, and 0 otherwise. EPROCEEDS is the expected amount to be raised in the offering (file price $x$ file shares) in millions of 2007 dollars. AGE is the number of years between the IPO date and the company's founding date. UWREP is the average Carter and Manaster (1990) underwriter rating of all lead underwriters in the IPO. NMGR is the number of managing underwriters in the syndicate. VENTURE is equal to 1 when the IPO is VC-backed, and 0 otherwise. The market value of equity, MV, is the number of shares outstanding times the close price on the first day of trading, in millions of 2007 dollars. BV is the book value of equity after the offer. PRADJ is the percentage increase in the offer price from the file price. FDRET is the percentage increase in the first trading day closing market price from the offer price. Style-adjusted buy-and-hold abnormal returns (BHARs) are calculated as the difference between the IPO's buy-and-hold return and the buy-and-hold return from an equal-weighted portfolio matched on size and book-to-market. The sample includes IPOs from 1982 to 2007.

\begin{tabular}{lcrrrrr}
\hline Variables & $\mathrm{N}$ & Mean & Std Dev & Median & Min & Max \\
\hline \multicolumn{7}{l}{ Panel A: Industry, Firm and Offer Characteristics } \\
\hline IGROW (\%) & 7608 & 18.16 & 7.26 & 16.09 & 5.35 & 43.83 \\
IDISP (\%) & 7602 & 22.38 & 8.52 & 20.18 & 0.00 & 141.40 \\
TECH & 7608 & 0.45 & 0.50 & 0.00 & 0.00 & 1.00 \\
INTERNET & 7608 & 0.06 & 0.24 & 0.00 & 0.00 & 1.00 \\
EPROCEEDS & 7506 & 87.72 & 233.45 & 43.06 & 0.85 & 9414.60 \\
AGE & 7331 & 16.07 & 22.09 & 8.00 & 0.00 & 224.00 \\
UWREP & 6732 & 7.10 & 2.19 & 8.00 & 0.00 & 9.00 \\
NMGR & 7608 & 2.40 & 1.56 & 2.00 & 1.00 & 28.00 \\
VENTURE & 7608 & 0.36 & 0.48 & 0.00 & 0.00 & 1.00 \\
MV & 7608 & 431.52 & 1483.41 & 143.06 & 0.00 & 65579.43 \\
BV/MV & 6292 & 0.44 & 0.97 & 0.31 & -3.17 & 54.12 \\
\hline Panel B: Market Characteristics & & & & & \\
\hline PRADJ (\%) & 7579 & -0.27 & 21.53 & 0.00 & -98.44 & 344.44 \\
FDRET (\%) & 7608 & 17.44 & 39.26 & 6.25 & -70.45 & 697.50 \\
BHAR 1-Yr (\%) & 6176 & -0.06 & 110.80 & -16.32 & -297.16 & 2673.93 \\
BHAR 2-Yr (\%) & 6176 & 6.50 & 383.73 & -35.13 & -340.51 & 22355.66 \\
BHAR 3-Yr (\%) & 6176 & 5.30 & 406.60 & -49.29 & -437.11 & 17608.61 \\
\hline
\end{tabular}




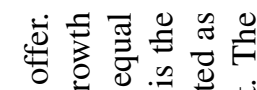

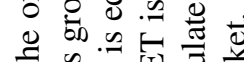

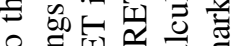

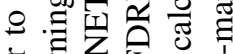
흘 可山的 考它氙 可

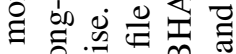
을 월 $\equiv$ फ . > ำ 웡

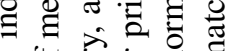
क पै है웡

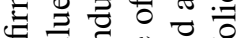
○ $\triangleq \circlearrowright$ y .

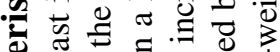

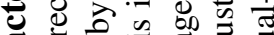
훙 뭉 I

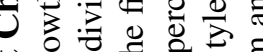
- bo 幺 क

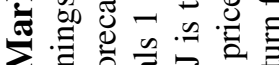

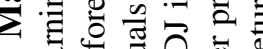

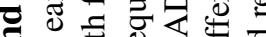
ప 屯ั

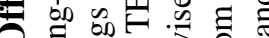
ㅎ․ㄹ

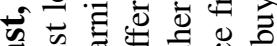

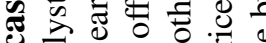
ปั ส ส

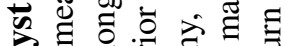

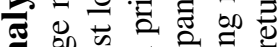

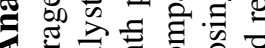

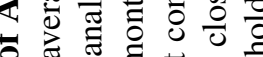

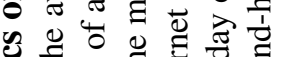
$\approx \neq \pm$ च

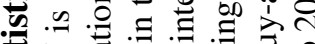

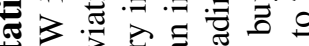
क 吾

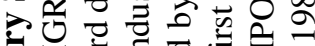

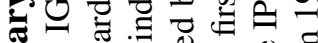

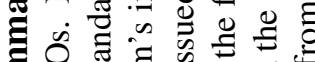

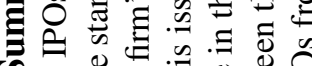
क 40.0

늉예

ॠ

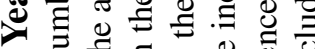

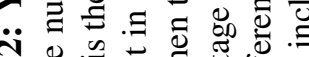

$\ddot{\sim} \otimes$.

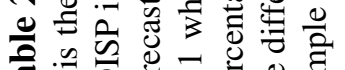

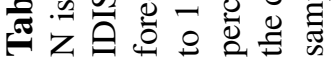

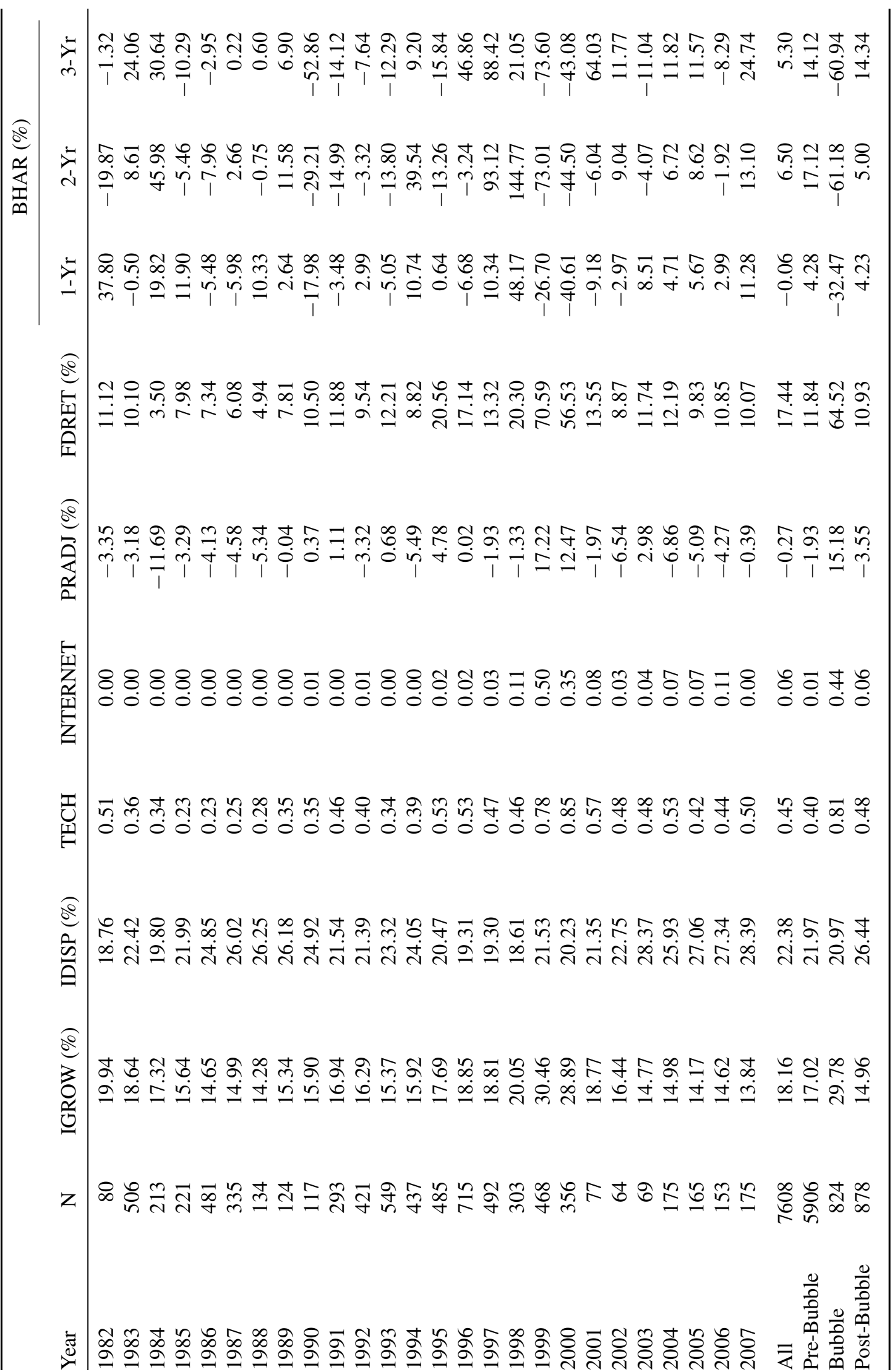




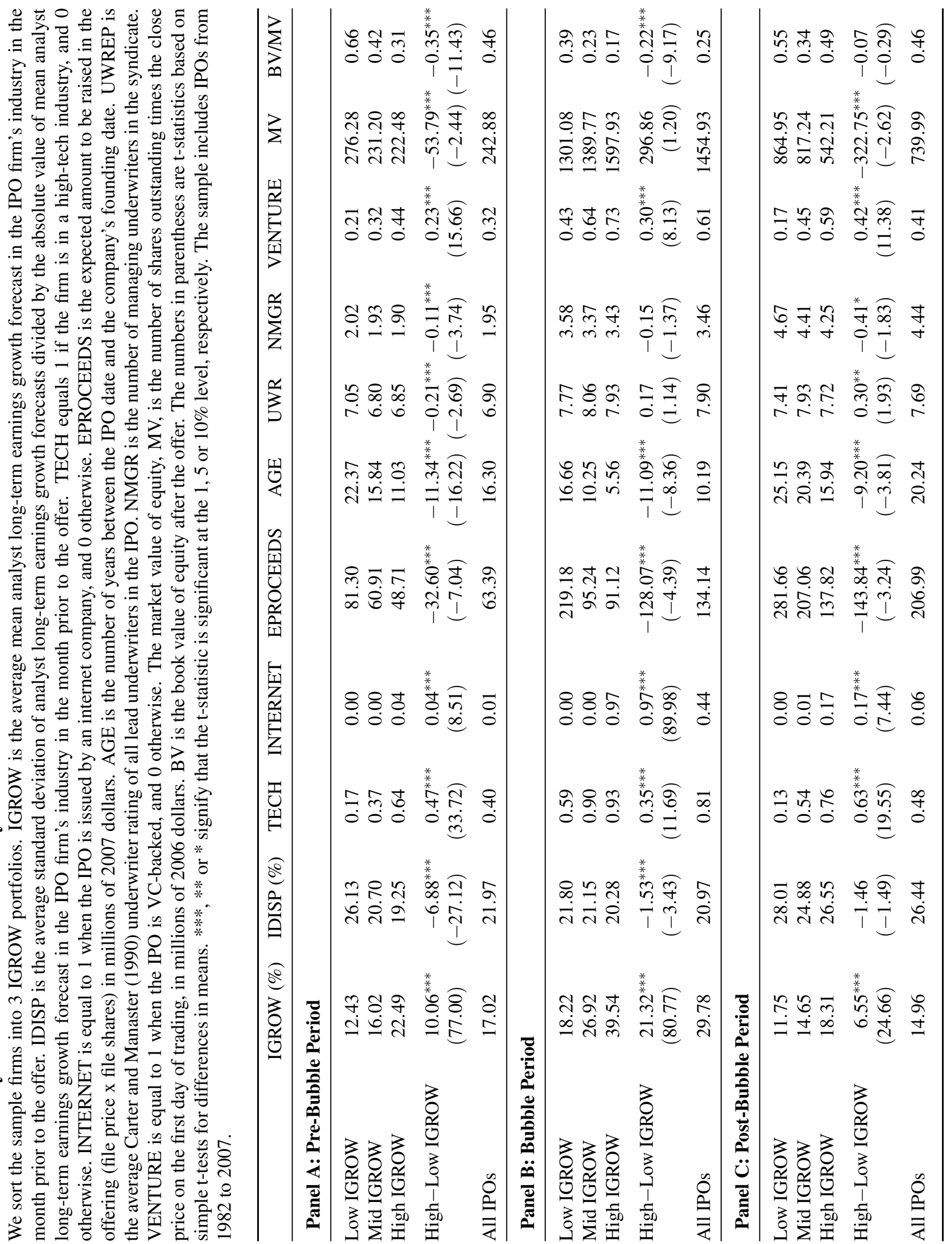


Table 4: Short and Long-Run Returns of Industry Growth Portfolios: Pre-Bubble Period Sample firms are sorted into 3 IGROW portfolios. IGROW is the average mean analyst long-term earnings growth forecast in the IPO firm's industry in the month prior to the offer. Style-adjusted buy-and-hold abnormal returns (BHARs) are calculated as the difference between the IPO's buy-and-hold return and the buy-and-hold return from an equal-weighted portfolio matched on size and book-to-market. The numbers in parentheses are t-statistics based on simple t-tests for differences in means. The numbers in brackets are empirical p-values based on observed significance levels from a randomization procedure designed to control for clustering, autocorrelation, and skewness of the original sample under the null hypothesis. $* * *, * *$ or $*$ signify that the t-statistic is significant at the 1,5 or $10 \%$ level, respectively. The sample includes IPOs from 1982 to 2007. The Pre-Bubble, Bubble, and Post-Bubble periods include IPOs from 1982 to 1998, 1999 to 2000 , and 2001 to 2007, respectively.

\begin{tabular}{|c|c|c|c|c|c|}
\hline & PRADJ $(\%)$ & FDRET $(\%)$ & 1-Yr BHAR (\%) & 2-Yr BHAR (\%) & 3-Yr BHAR $(\%$ \\
\hline \multicolumn{6}{|c|}{ Panel A: Equal-Weighted Portfolios } \\
\hline Low IGROW & -3.51 & 8.96 & -2.42 & -3.76 & -6.26 \\
\hline Mid IGROW & -3.31 & 10.92 & 0.63 & -5.95 & -9.87 \\
\hline High IGROW & 1.02 & 15.58 & 14.41 & 60.80 & 58.25 \\
\hline High-Low IGROW & $4.53^{* * *}$ & $6.62^{* * *}$ & $16.84^{* * *}$ & $64.56^{* * *}$ & $64.51^{* * *}$ \\
\hline & (7.95) & (9.13) & $(4.57)$ & $(3.45)$ & $(3.36)$ \\
\hline & {$[0.00]$} & {$[0.00]$} & {$[0.00]$} & {$[0.00]$} & {$[0.00]$} \\
\hline All IPOs & $-1.93^{* * *}$ & $11.84^{* * *}$ & $4.28^{* * *}$ & $17.12^{* * *}$ & $14.12^{* *}$ \\
\hline \multicolumn{6}{|c|}{ Panel B: Value-Weighted Portfolios } \\
\hline Low IGROW & 0.81 & 10.10 & -0.13 & -5.25 & -7.72 \\
\hline Mid IGROW & 3.23 & 16.34 & -0.20 & -4.63 & -3.61 \\
\hline High IGROW & 11.04 & 28.61 & 41.99 & 185.95 & 157.87 \\
\hline \multirow[t]{3}{*}{ High-Low IGROW } & $10.23^{* * *}$ & $18.51^{* * *}$ & $42.12^{* * *}$ & $191.19^{* * *}$ & $165.58^{* * *}$ \\
\hline & (16.20) & $(18.56)$ & $(8.20)$ & $(5.96)$ & $(6.21)$ \\
\hline & {$[0.00]$} & {$[0.00]$} & {$[0.00]$} & {$[0.00]$} & {$[0.00]$} \\
\hline All IPOs & $4.73^{* * *}$ & $17.79^{* * *}$ & $13.68^{* * *}$ & $57.78^{* * *}$ & $48.12^{* * *}$ \\
\hline
\end{tabular}


Table 5: Short and Long-Run Returns of Industry Growth Portfolios: Bubble Period Sample firms are sorted into 3 IGROW portfolios. IGROW is the average mean analyst long-term earnings growth forecast in the IPO firm's industry in the month prior to the offer. Style-adjusted buy-and-hold abnormal returns (BHARs) are calculated as the difference between the IPO's buy-and-hold return and the buy-and-hold return from an equal-weighted portfolio matched on size and book-to-market. The numbers in parentheses are t-statistics based on simple t-tests for differences in means. The numbers in brackets are empirical p-values based on observed significance levels from a randomization procedure designed to control for clustering, autocorrelation, and skewness of the original sample under the null hypothesis. $* * *, * *$ or $*$ signify that the t-statistic is significant at the 1,5 or $10 \%$ level, respectively. The sample includes IPOs from 1982 to 2007. The Pre-Bubble, Bubble, and Post-Bubble periods include IPOs from 1982 to 1998, 1999 to 2000 , and 2001 to 2007, respectively.

\begin{tabular}{|c|c|c|c|c|c|}
\hline & PRADJ $(\%)$ & FDRET (\%) & 1-Yr BHAR (\%) & 2-Yr BHAR $(\%)$ & 3-Yr BHAR $(\%)$ \\
\hline \multicolumn{6}{|c|}{ Panel A: Equal-Weighted Portfolios } \\
\hline Low IGROW & 3.86 & 37.11 & -16.15 & -34.51 & -50.14 \\
\hline Mid IGROW & 10.61 & 53.30 & -21.40 & -50.86 & -38.35 \\
\hline High IGROW & 25.66 & 89.80 & -50.09 & -86.11 & -80.22 \\
\hline High-Low IGROW & $21.80^{* * *}$ & $52.68^{* * *}$ & $-33.94^{* *}$ & $-51.60^{* * *}$ & $-30.08^{* * *}$ \\
\hline & $(7.29)$ & (7.34) & $(-2.00)$ & $(-4.64)$ & $(-3.09)$ \\
\hline & {$[0.00]$} & {$[0.00]$} & {$[0.04]$} & {$[0.00]$} & {$[0.00]$} \\
\hline All IPOs & $15.18^{* * *}$ & $64.52^{* * *}$ & $-32.47^{* * *}$ & $-61.18^{* * *}$ & $-60.94^{* * *}$ \\
\hline \multicolumn{6}{|c|}{ Panel B: Value-Weighted Portfolios } \\
\hline Low IGROW & 24.00 & 78.43 & -12.26 & -19.99 & -21.63 \\
\hline Mid IGROW & 66.09 & 127.78 & -37.93 & -57.81 & -46.41 \\
\hline High IGROW & 60.31 & 182.53 & -47.51 & -85.82 & -77.47 \\
\hline \multirow[t]{3}{*}{ High-Low IGROW } & $36.31^{* * *}$ & $104.10^{* * *}$ & $-35.25^{* * *}$ & $-65.83^{* * *}$ & $-55.84^{* * *}$ \\
\hline & $(8.70)$ & $(9.08)$ & $(-2.53)$ & $(-9.04)$ & $(-7.83)$ \\
\hline & {$[0.00]$} & {$[0.01]$} & {$[0.04]$} & {$[0.00]$} & {$[0.00]$} \\
\hline All IPOs & $50.91^{* * *}$ & $140.54^{* * *}$ & $-34.50^{* * *}$ & $-59.98^{* * *}$ & $-54.42^{* * *}$ \\
\hline
\end{tabular}


Table 6: Short and Long-Run Returns of Industry Growth Portfolios: Post-Bubble Period Sample firms are sorted into 3 IGROW portfolios. IGROW is the average mean analyst long-term earnings growth forecast in the IPO firm's industry in the month prior to the offer. Style-adjusted buy-and-hold abnormal returns (BHARs) are calculated as the difference between the IPO's buy-and-hold return and the buy-and-hold return from an equal-weighted portfolio matched on size and book-to-market. The numbers in parentheses are t-statistics based on simple t-tests for differences in means. The numbers in brackets are empirical p-values based on observed significance levels from a randomization procedure designed to control for clustering, autocorrelation, and skewness of the original sample under the null hypothesis. ***, ** or * signify that the t-statistic is significant at the 1,5 or $10 \%$ level, respectively. The sample includes IPOs from 1982 to 2007. The Pre-Bubble, Bubble, and Post-Bubble periods include IPOs from 1982 to 1998, 1999 to 2000 , and 2001 to 2007, respectively.

\begin{tabular}{|c|c|c|c|c|c|}
\hline & $\operatorname{PRADJ}(\%)$ & FDRET (\%) & 1-Yr BHAR $(\%)$ & 2-Yr BHAR $(\%)$ & 3-Yr BHAR (\%) \\
\hline \multicolumn{6}{|c|}{ Panel A: Equal-Weighted Portfolios } \\
\hline Low IGROW & -1.54 & 8.16 & 9.88 & 15.85 & 46.15 \\
\hline Mid IGROW & -5.27 & 11.54 & -3.19 & 2.21 & -5.86 \\
\hline High IGROW & -3.64 & 12.92 & 6.55 & -1.61 & 6.56 \\
\hline High-Low IGROW & $\begin{array}{r}-2.10 \\
(-1.34) \\
{[0.00]}\end{array}$ & $\begin{array}{l}4.76^{* * *} \\
(3.06) \\
{[0.18]}\end{array}$ & $\begin{array}{r}-3.33 \\
(-0.42) \\
{[0.68]}\end{array}$ & $\begin{array}{r}-17.46^{*} \\
(-1.67) \\
{[0.10]}\end{array}$ & $\begin{array}{r}-39.59 \\
(-1.42) \\
{[0.15]}\end{array}$ \\
\hline All IPOs & $-3.55^{* * *}$ & $10.93^{* * *}$ & 4.23 & 5.00 & 14.34 \\
\hline \multicolumn{6}{|c|}{ Panel B: Value-Weighted Portfolios } \\
\hline Low IGROW & -0.26 & 16.80 & 24.39 & 24.94 & 26.35 \\
\hline Mid IGROW & 7.15 & 18.42 & 2.85 & 16.15 & 22.45 \\
\hline High IGROW & 3.17 & 19.30 & 17.48 & 11.68 & 29.96 \\
\hline High-Low IGROW & $\begin{array}{l}3.43^{* *} \\
(2.20) \\
{[0.77]}\end{array}$ & $\begin{array}{c}2.49 \\
(1.11) \\
{[0.43]}\end{array}$ & $\begin{array}{r}-6.91 \\
(-0.77) \\
{[0.70]}\end{array}$ & $\begin{array}{r}-13.26 \\
(-1.20) \\
{[0.54]}\end{array}$ & $\begin{array}{c}3.61 \\
(0.24) \\
{[0.90]}\end{array}$ \\
\hline All IPOs & $3.43^{* * *}$ & $18.03^{* * *}$ & $14.63^{* * *}$ & $18.28^{* * *}$ & $25.82^{* * *}$ \\
\hline
\end{tabular}


Table 7: Regressions of Price Adjustment and First-Day Returns on Industry Growth and Control Variables

IGROW is the average mean analyst long-term earnings growth forecast in the IPO firm's industry in the month prior to the offer. IDISP is the average standard deviation of analyst long-term earnings growth forecasts divided by the absolute value of mean analyst long-term earnings growth forecast in the IPO firm's industry in the month prior to the offer. AGE is the number of years between the IPO date and the company's founding date. UWREP is the average Carter and Manaster (1990) underwriter rating of all lead underwriters in the IPO. NMGR is the number of managing underwriters in the syndicate. VENTURE is equal to 1 when the IPO is VC-backed, and 0 otherwise. EPROCEEDS is the expected amount to be raised in the offering (file price $\mathrm{x}$ file shares) in millions of 2007 dollars. TECH equals 1 if the firm is in a high-tech industry, and 0 otherwise. PRADJ is the percentage increase in the offer price from the file price. FDRET is the percentage increase in the first trading day closing market price from the offer price. The numbers in parentheses are heteroscedasticity consistent t-statistics. ***,** or * signify that the t-statistic is significant at the 1,5 or $10 \%$ level, respectively. The sample includes IPOs from 1982 to 2007. The Pre-Bubble, Bubble, and Post-Bubble periods include IPOs from 1982 to 1998, 1999 to 2000, and 2001 to 2007, respectively.

\begin{tabular}{|c|c|c|c|c|c|c|}
\hline & \multicolumn{2}{|c|}{ Pre-Bubble } & \multicolumn{2}{|c|}{ Bubble } & \multicolumn{2}{|c|}{ Post-Bubble } \\
\hline & PRADJ & FDRET & PRADJ & FDRET & PRADJ & FDRET \\
\hline \multirow[t]{2}{*}{ IGROW } & $0.46^{* * *}$ & $0.65^{* * *}$ & $0.99^{* * *}$ & $2.21^{* * *}$ & 0.04 & 0.30 \\
\hline & $(7.17)$ & (5.91) & (5.99) & (7.02) & $(0.18)$ & $(1.39)$ \\
\hline \multirow[t]{2}{*}{ IDISP } & -0.02 & $-0.06^{*}$ & $0.30^{*}$ & 0.19 & -0.07 & $-0.10^{* *}$ \\
\hline & $(-0.82)$ & $(-1.72)$ & (1.95) & $(0.60)$ & $(-1.30)$ & $(-2.05)$ \\
\hline \multirow[t]{2}{*}{$\operatorname{Ln}(1+A G E)$} & $-0.42^{*}$ & $-1.56^{* * *}$ & 0.42 & -4.47 & $-1.15^{*}$ & 0.37 \\
\hline & $(-1.91)$ & $(-6.12)$ & $(0.24)$ & $(-1.38)$ & $(-1.83)$ & $(0.59)$ \\
\hline \multirow[t]{2}{*}{ UWREP } & $0.82^{* * *}$ & 0.20 & $4.17^{* * *}$ & $13.91^{* * *}$ & $2.00^{* * *}$ & $1.80^{* * *}$ \\
\hline & $(5.80)$ & (1.06) & (4.99) & $(6.84)$ & $(3.80)$ & (3.66) \\
\hline \multirow[t]{2}{*}{ Ln(NMGR) } & $4.29^{* * *}$ & $4.34^{* * *}$ & 5.85 & 2.87 & 0.30 & 2.72 \\
\hline & (6.09) & (6.16) & (1.39) & $(0.30)$ & $(0.10)$ & (1.43) \\
\hline \multirow[t]{2}{*}{ VENTURE } & -0.04 & 0.20 & 0.13 & 8.18 & $-3.35^{*}$ & $5.31^{* * *}$ \\
\hline & $(-0.06)$ & $(0.25)$ & $(0.05)$ & $(1.29)$ & $(-1.89)$ & (3.21) \\
\hline \multirow[t]{2}{*}{ Ln(EPROCEEDS) } & $-2.06^{* * *}$ & $-1.64^{* * *}$ & $-8.87^{* *}$ & $-16.27^{* * *}$ & -0.56 & $-3.05^{* * *}$ \\
\hline & $(-5.77)$ & $(-4.71)$ & $(-2.11)$ & $(-3.79)$ & $(-0.28)$ & $(-3.08)$ \\
\hline \multirow[t]{2}{*}{$\mathrm{TECH}$} & 0.88 & $1.68^{* *}$ & 2.16 & 2.52 & $-4.18^{* *}$ & -2.27 \\
\hline & (1.43) & $(2.41)$ & (0.64) & $(0.40)$ & $(-2.22)$ & $(-1.34)$ \\
\hline \multirow[t]{2}{*}{ Intercept } & $-9.29^{* * *}$ & $6.81^{* *}$ & -25.27 & $-48.11^{* * *}$ & -9.45 & 5.24 \\
\hline & $(-5.29)$ & (2.51) & $(-1.59)$ & $(-3.12)$ & $(-1.41)$ & $(0.95)$ \\
\hline Adj. $R^{2}$ & 0.045 & 0.060 & 0.124 & 0.156 & 0.032 & 0.053 \\
\hline $\mathrm{N}$ & 4962 & 4962 & 718 & 718 & 750 & 750 \\
\hline
\end{tabular}




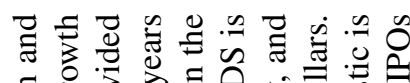

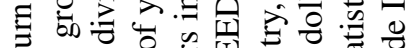

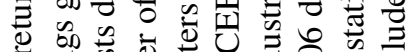
글

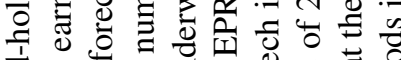

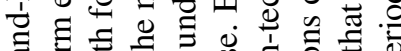
\% ob

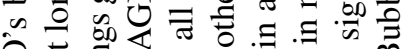

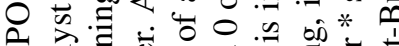

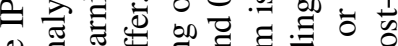

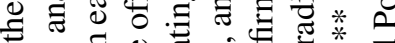
可

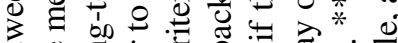
요의.

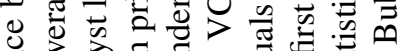

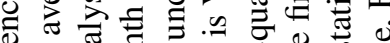

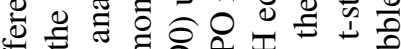
$y=0$ 응 0 o

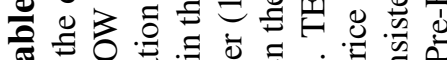

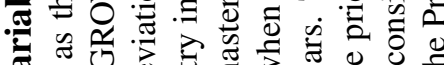

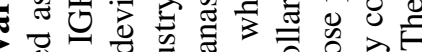

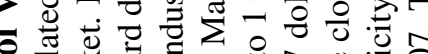

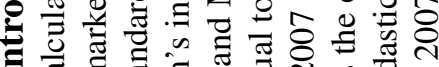

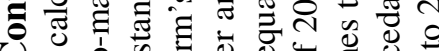
U

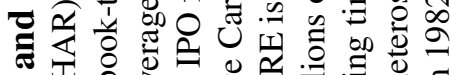

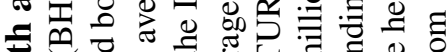

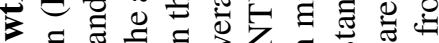

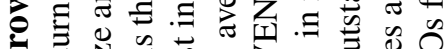
는

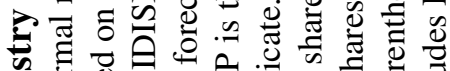

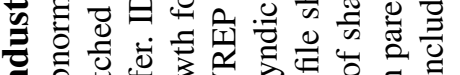

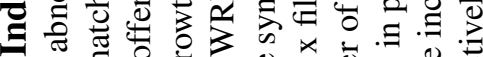
5 등

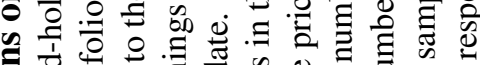

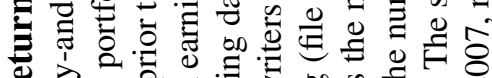

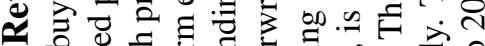

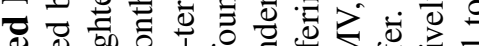

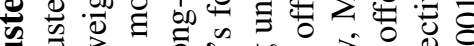

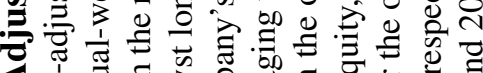

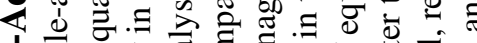

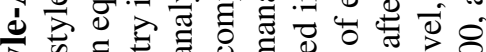

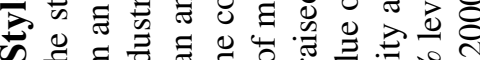
औ 0.4 .

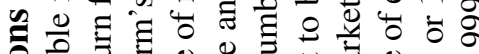
然递

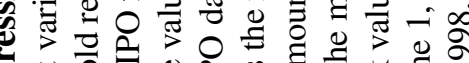
㩆敦

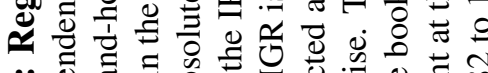

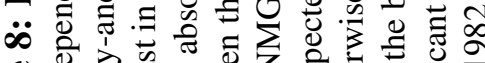

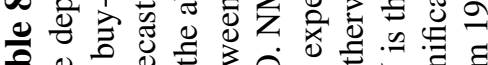

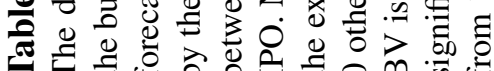

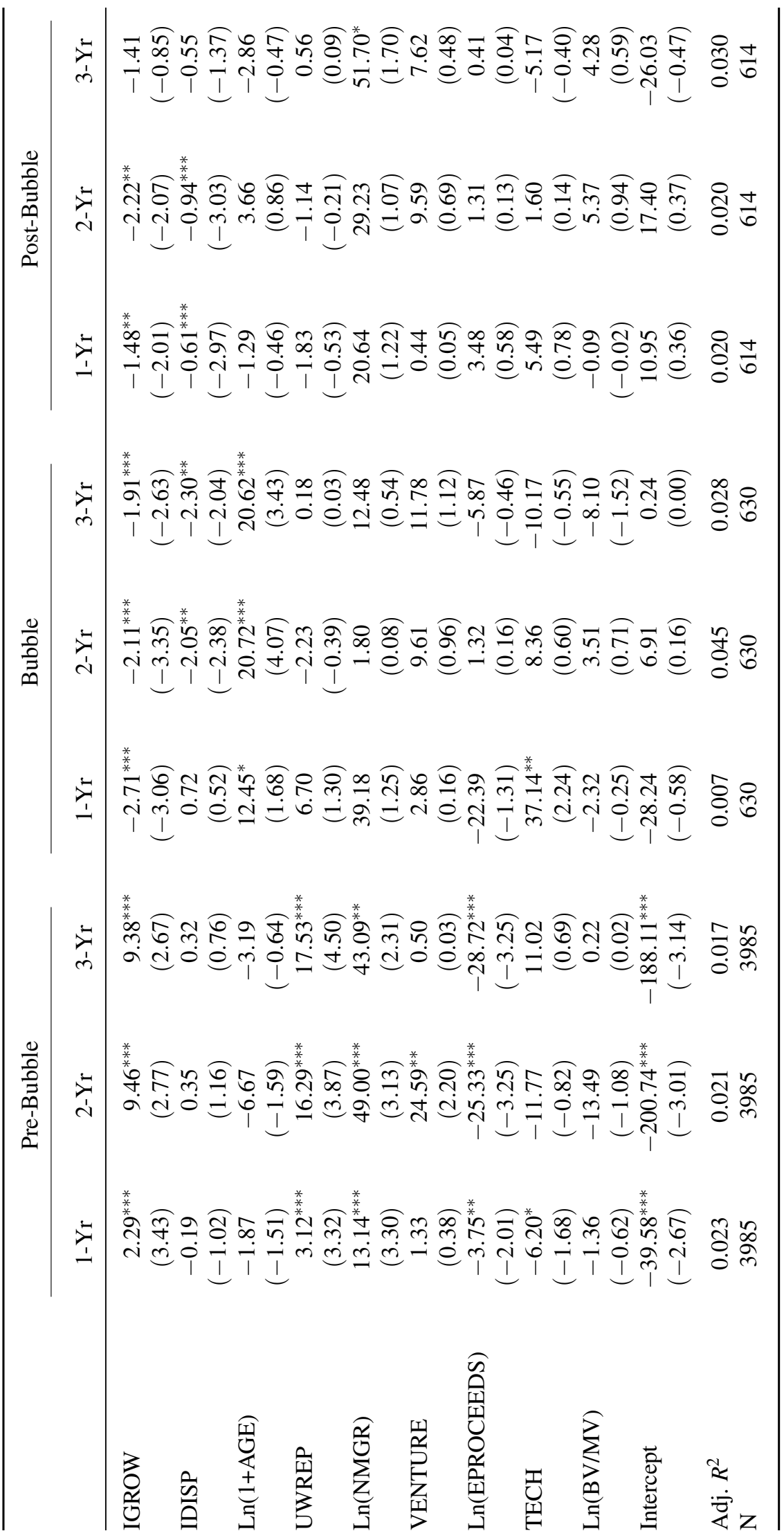


Table 9: 3-Year Calendar-Time 5-Factor Regressions for Industry Growth Portfolios

This table reports the intercepts of five-factor regressions of equal-weighted (Panel A) or value-weighted (Panel B) monthly returns of low, medium and high IGROW portfolios. The portfolios are constructed by allocating IPOs to low, medium or high IGROW portfolios as they become public. The IPOs remain in their respective portfolios for up to 3 years after which time they drop out. The regression model is given by: $R_{p t}-R_{f t}=a+b\left(R_{m t}-R_{f t}\right)+s S M B_{t}+h H M L_{t}+m U M D_{t}+i I N V_{t}+e_{t} . R_{p t}$ is the monthly portfolio return. $R_{f t}$ is the 1-month treasury bill return. $R_{m t}$ is the monthly value-weighted return on all NYSE, AMEX, and Nasdaq stocks. $S M B_{t}$ (Small Minus Big) is the average monthly return on the three small portfolios minus the average return on the three big portfolios. $H M L_{t}$ (High Minus Low) is the average monthly return on the two value portfolios minus the average return on the two growth portfolios. $U M D_{t}$ is the average return on the two high prior return portfolios minus the average return on the two low prior return portfolios. $I N V_{t}$ is the investment factor from Lyandres, Sun and Zhang (2008). The numbers in parentheses are t-statistics. $* * *, * *$ or $*$ signify that the t-statistic is significant at the 1,5 or $10 \%$ level, respectively. The sample includes IPOs from 1982 to 2007. The Pre-Bubble, Bubble, and Post-Bubble periods include IPOs from 1982 to 1998, 1999 to 2000, and 2001 to 2007, respectively. Returns for the afore mentioned periods are taken between 1983 and 1999 (204 observations), 2000 and 2001 (24 observations), and 2002 and 2008 (84 observations), respectively, to allow for there to be sufficient firms in each portfolio.

\begin{tabular}{lccc}
\hline & Pre-Bubble & Bubble & Post-Bubble \\
\hline \multicolumn{1}{c}{ Panel A: Equal-Weighted Portfolios } & & \\
\hline Low IGROW & $-0.39^{* *}$ & 0.37 & -0.27 \\
Mid IGROW & $(-2.08)$ & $(0.40)$ & $-1.08)$ \\
& $-0.58^{* * *}$ & -0.15 & -0.22 \\
High IGROW & $(-2.94)$ & $(-0.08)$ & $-0.69)$ \\
& 0.28 & -3.26 & $(-1.17)$ \\
High-Low IGROW & $(1.26)$ & $(-1.36)$ & -0.19 \\
& $0.67^{* * *}$ & $-3.62^{*}$ & $(-0.43)$ \\
All IPOs & $(2.64)$ & $(-1.91)$ & -0.32 \\
& -0.23 & -1.04 & $(-1.40)$ \\
\hline Panel B: Value-Weighted Portfolios & & $(-0.65)$ & $(0.11$ \\
\hline Low IGROW & $-1.44)$ & & -0.08 \\
Mid IGROW & $-0.38^{*}$ & -0.18 & $(-0.26)$ \\
High IGROW & $-1.92)$ & $(-0.30)$ & -0.03 \\
& $\left(-0.44^{* *}\right.$ & 0.63 & $(-0.06)$ \\
High-Low IGROW & $0.80^{* * *}$ & $-4.66^{* *}$ & -0.15 \\
All IPOs & $(3.21)$ & $(-2.10)$ & $(-0.25)$ \\
& $1.19^{* * *}$ & $-4.48^{*}$ & 0.11 \\
& $(3.69)$ & $(-1.88)$ & $(0.40)$ \\
\hline
\end{tabular}


Table 10: Industry Growth of Completed and Withdrawn IPOs

We sort the sample firms into 3 IGROW portfolios. IGROW is the average mean analyst long-term earnings growth forecast in the IPO firm's industry in the month prior to the offer. The numbers in parentheses are tstatistics based on simple t-tests for differences in means. $* * *, * *$ or * signify that the t-statistic is significant at the 1,5 or $10 \%$ level, respectively. The sample includes IPOs from 1982 to 2007. The Pre-Bubble, Bubble, and Post-Bubble periods include IPOs from 1982 to 1998, 1999 to 2000, and 2001 to 2007, respectively.

\begin{tabular}{lcc}
\hline & N & IGROW (\%) \\
\hline Panel A: Pre-Bubble Period & & \\
\hline Completed & 5906 & 17.02 \\
Withdrawn & 848 & 15.97 \\
Completed-Withdraw & & $1.05^{* * *}$ \\
& & $5.34)$ \\
All IPOs & 6754 & 16.89 \\
\hline Panel B: Bubble Period & & \\
\hline Completed & 824 & 29.78 \\
Withdrawn & 182 & 21.19 \\
Completed-Withdraw & & $8.59^{* * *}$ \\
All IPOs & 1006 & $(10.93)$ \\
\hline Panel C: Post-Bubble Period & & 28.23 \\
\hline Completed & 878 & \\
Withdrawn & 244 & 14.96 \\
Completed-Withdraw & & 17.27 \\
& & $-2.32^{* * *}$ \\
All IPOs & 1122 & $(-7.93)$ \\
\hline
\end{tabular}


Table 11: Logistic Regressions of IPO Withdrawal on Industry Growth and Control Variables The dependent variable equals 1 if a firm withdrew their IPO, and 0 if a firm completed their IPO. IGROW is the average mean analyst long-term earnings growth forecast in the IPO firm's industry in the month prior to the offer. IDISP is the average standard deviation of analyst long-term earnings growth forecasts divided by the absolute value of mean analyst long-term earnings growth forecast in the IPO firm's industry in the month prior to the offer. UWREP is the average Carter and Manaster (1990) underwriter rating of all lead underwriters in the IPO. NMGR is the number of managing underwriters in the syndicate. VENTURE is equal to 1 when the IPO is VC-backed, and 0 otherwise. EPROCEEDS is the expected amount to be raised in the offering (file price $\mathrm{x}$ file shares) in millions of 2007 dollars. TECH equals 1 if the firm is in a high-tech industry, and 0 otherwise. MBHR is the CRSP equal-weighted index buy-and-hold return over the 30 day period prior to the offer date, using daily returns. MVOL is the CRSP equal-weighted index daily return standard deviation over the 30 day period prior to the offer date. The numbers in parentheses are Chi-squarestatistics. $* * *, * *$ or * signify that the Chi-square-statistic is significant at the 1,5 or $10 \%$ level, respectively. The sample includes IPOs from 1982 to 2007. The Pre-Bubble, Bubble, and Post-Bubble periods include IPOs from 1982 to 1998,1999 to 2000, and 2001 to 2007, respectively.

\begin{tabular}{lccc}
\hline & Pre-Bubble & Bubble & Post-Bubble \\
\hline IGROW & $-0.02^{* *}$ & $-0.08^{* * *}$ & $0.08^{* * *}$ \\
& $(4.06)$ & $(29.33)$ & $(8.73)$ \\
IDISP & -0.00 & -0.02 & $0.02^{*}$ \\
& $(0.22)$ & $(1.47)$ & $(3.44)$ \\
UWREP & 0.04 & $0.18^{* *}$ & $0.25^{* * *}$ \\
& $(2.19)$ & $(5.60)$ & $(9.44)$ \\
Ln(NMGR) & -0.03 & $-0.89^{* * *}$ & $-1.00^{* * *}$ \\
& $(0.07)$ & $(8.21)$ & $(12.41)$ \\
VENTURE & $-3.02^{* * *}$ & $-5.37^{* * *}$ & $-4.93^{* * *}$ \\
& $(143.83)$ & $(28.05)$ & $(44.15)$ \\
Ln(EPROCEEDS) & 0.08 & -0.26 & -0.17 \\
& $(2.14)$ & $(2.57)$ & $(1.12)$ \\
TECH & 0.17 & $0.52^{*}$ & $1.04^{* * *}$ \\
& $(2.52)$ & $(3.67)$ & $(19.80)$ \\
MBHR & $-0.02^{*}$ & -0.01 & -0.02 \\
& $(2.71)$ & $(0.49)$ & $(1.31)$ \\
MVOL & $0.45^{* * *}$ & $0.75^{* *}$ & $1.99^{* * *}$ \\
Intercept & $(6.81)$ & $(5.85)$ & $(29.83)$ \\
& $-2.01^{* * *}$ & $1.58^{* *}$ & $-4.45^{* * *}$ \\
Adj. $R^{2}$ & $(49.51)$ & $(5.92)$ & $(36.52)$ \\
$\mathrm{N}$ & 0.069 & 0.300 & 0.272 \\
& 5836 & 893 & 952 \\
\hline
\end{tabular}

